\title{
Assessment of Dome-Fill \\ Technology and Potential Fill \\ Materials for the Hanford \\ Single-Shell Tanks
}

J. D. Smyth

J. W. Shade

S. Somasundaram

May 1992

Prepared for the U.S. Department of Energy under Contract DE-AC06-76RLO 1830

Pacific Northwest Laboratory

Operated for the U.S. Department of Energy

by Battelle Memorial Institute 


\title{
DISCLAIMER
}

This report was prepared as an account of work sponsored by an agency of the United States Government. Neither the United States Government nor any agency thereof, nor Battelle Memorial Institute, nor any of their employees, makes any warranty, expressed or implied, or assumes any legal liability or responsibility for the accuracy, completeness, or usefulness of any information, apparatus, product, or process disclosed, or represents that its use would not infringe privately owned rights. Reference herein to any specific commercial product, process, or service by trade name, trademark, manufacturer, or otherwise does not necessarily constitute or imply its endorsement, recommendation, or favoring by the United States Government or any agency thercof, or Battelle Memorial Institute. The views and opinions of authors expressed herein do not necessarily state or reflect those of the United States Government or any agency thereof.

\author{
PACIFIC NORTHWEST LABORATORY \\ operated by \\ BATTELLE MEMORIAL INSTITUTE \\ for the \\ UNITED STATES DEPARTMENT OF ENERGY \\ under Contract DE-ACO6-76RLO 1830
}

Printed in the United States of America

Available to DOE and DOE contractors from the

Office of Scientific and Technical Information, P.O. Box 62, Oak Ridge, TN 37831; prices ayailable from (615) 576-8401. FTS 626-8401.

Available to the public from the National Technical Information Service, U.S. Department of Commerce, 5285 Port Royal Rd., Springfield, VA 22161. 
FNL- -8014

DE92 014599

A Research Report for Westinghouse Hanford Company

ASSESSMENT OF DOME-FILL TECHNOLOGY

AND POTENTIAL FILL MATERIALS FOR

THE HANFORD SINGLE-SHELL TANKS
J. D. Smyth
J. W. Shade
S. Somasundaram

May 1992

Prepared for

the U.S. Department of Energy

under Contract DE-ACD6-76RLO 1830

Pacific Northwest Laboratory

Richland, Washington 99352

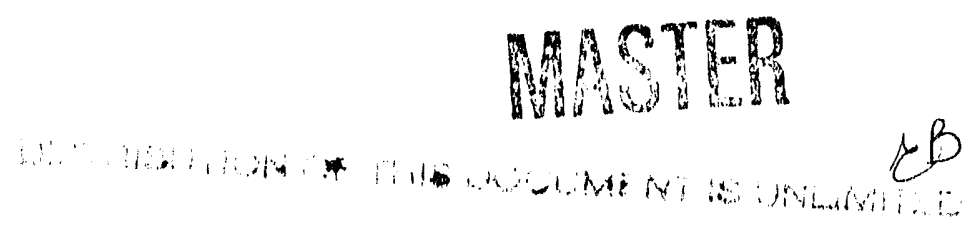




\section{SUMMARY}

This study is part of a task that will identify dome-fill materials to stabilize and prevent the collapse of the structures of 149 single-shell tanks (SSTS). The SSTs were built at the Hanford Site in Washington State and used between 1944 and 1980 to store radioactive and other hazardous wastes. In addition to identifying suitable fill materials (referred to as "dome-fill" in this report), this task will develop the technology and methods required to fill the tanks with the selected material. To date, basalt is the only candidate fill material with any testing conducted for its suitability as a domefill material. Sufficient data do not exist to select or eliminate basalt as a candidate material.

This report documents a review of past dome-fill work at the Hanford Site and of other pertinent literature to establish a baseline for the dome-fill technology. In addition, the report identifies existing dome-fill technology, preliminary performance criteria for dome-fill technology development, potential testing strategies, and potential fill materials. As a part of this study, potential fill materials are qualitatively evaluated and a list of preliminary candidate fill materials is identified. Future work will further screen these materials. The dome-fill task work will ultimately contribute to the development of a final waste form package and the safe isolation of wastes from the Hanford Site SSTs. Interfaces with parallel technology development projects, including in situ vitrification of the SSTs and the development of protective barriers, must be established to ensure proper selection of domefill material. 


\section{CONTENTS}

SUMMARY ..................................

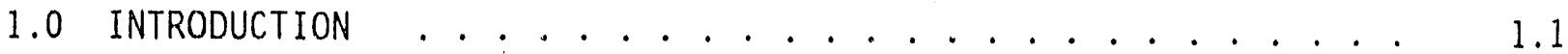

1.1 THE DOME-FILL TASK . . . . . . . . . . . . 1.5

1.2 OVERVIEW OF REPORT . . . . . . . . . . . . . 1.7

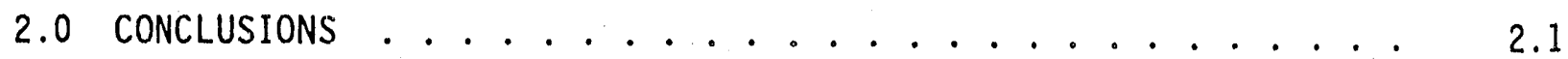

2.1 DOME-FILL TECHNOLOGY ASSESSMENT . . . . . . . . 2.1

2.2 SCOPING STUEIES . . . . . . . . . . . . 2.1

3.0 REVIEW OF PREVIOUS DOME-FILL STUdIES . . . . . . . . . . 3.1

3.1 DEVELOPMENT OF THE DOME-FILL CONCEPT . . . . . . . . 3.1

3.1.1 Development of Criteria for Candidate
Dome-fill Tanks . . . . . . . . 3.2

3.1.2 Dome-Fil1 Technology Development and Planning ... 3.3

3.1.3 Laboratory Studies of Basalt/Waste Interaction . . 3.4

3.1.4 Summary of the Initial Dome-fill Effort . . . . 3.6

3.2 PROPOSALS FOR SELECTING AND EVALUATING

DOME-FILL MATERIALS $\ldots \ldots \ldots . \ldots . \ldots . \ldots$

3.2.1 Material Selection Criteria ......... 3.7

3.2.2 Screening/Selection Methodology . . . . . . . 3.7

3.2.3 Final Selection and Evaluation ........ . . . 3.8

3.3 DEVELOPMENT OF A REVISED DOME-FILL TECHMOLOGY PLAN . . . . . 3.8

3.3.1 Criteria and Standards Development ...... 3.9

3.3.2 Evaluation of Dome-Fill Alternatives . . . . 3.9

3.3.3 Dome-Fill Settlement Evaluation ........ . 3.9

3.3.4 Fill Material Analysis . . . . . . . . . 3.10

3.3.5 Dome-Fill Test Development . . . . . . . 3.10 
3.3.6 Results of the Revised Dome-Fill Technology Plan . . 3.11

3.4 SUMMARY OF HANFORD DOME-FILL. TECHNOLOGY HISTORY $\ldots . . . \quad$. 3.11

4.0 DOME-FILL TECHNOLOGY ISSUES . . . . . . . . . . . . . . . . 4.1

4.1 IDENTIFICATION OF THE DOME-FILL PERFORMANCE STANDARD . . . 4.1

4.1.1 Barrier Design .............. 4.2

4.1.2 Barrier Subsidence . . . . . . . . . . . 4.2

4.2 DOME-FILL SCENARIOS . . . . . . . . . . . . . . 4.2

4.2.1 SST Designs . . . . . . . . . . . . . . . . 4.3

4.3 RELATIONSHIP TO OTHER TECHNOLOGY DEVELOPMENT PROGRAMS . . 4.5

5.0 PRELIMINARY SELECTION OF DOME-FILL MATERIALS . . . . . . . . 5.1

5.1 PRELIMINARY SELECTION CRITERIA FOR FILL MATERIALS . . . . 5.2

5.1.1 Physical Properties . . . . . . . . . . . . 5.2

5.1.2 Chemical Properties ............... . 5.4

5.1.3 Predictive Model Development . . . . . . . . . 5.5

5.1.4 Economic Considerations . . . . . . . . . . 5.6

5.1.5 Transportation and Handling Considerations . . . 5.6

5.2 PRIMARY SELECTION METHODS . . . . . . . . . . . . . 5.6

5.2.1 Comparative Analys is of Fill-Material Properties . $\quad 5.7$

5.2.2 Analysis of Composite Fill Materials . . . . . 5.10

-5.2.3 Reaction Rates/Tolerable Dissolution ...... 5.11

5.3 PROPOSED TESTING APPROACHES . . . . . . . . . . . 5.11

5.4 PRELIMINARY LIST OF DOME-FILL MATERIALS . . . . . . . . 5.13

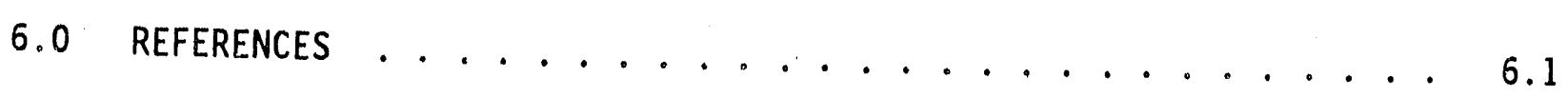




\section{FIGURES}

1.1 Disposal and Storage Options for Single-She11 Tank Wastes . . . 1.3

1.2 Locations of the Hanford Site and the Separations Areas . . . . 1.6

1.3 Dome-Fill Technology Development . . . . . . . . . . . . 1.7

1.4 Dome-Fill Technology Assessment and Selection of Preliminary
Candidate Fill Materials . . . . . . . . . . . . . . . . 1.8

4.1 Single-Shell Tank Types .................. . . 4.4

\section{TABLES}

5.1 Physical Properties of Some Common Minerals . . . . . . . 5.8

5.2 Additional Physical Properties of Common Minerals . . . . . . 5.9 


\subsection{INTRODUCTION}

The Pacific Northwest Laboratory (PNL) ${ }^{(a)}$ is developing technologies to i Hentify and provide final waste forms and packages for the disposal and safe isolation of wastes from the Hanford Site single-shell tanks (SSTs). The project, Preparation of Final Waste Packages, is sponsored by the Westinghouse Hanford Company (WHC) as part of the environmental restoration effort at Hanford.

Final waste forms must be identified for long-term storage and disposal of the SST wastes; technologies must be developed that will allow timely regulatory approval for disposal. Figure 1.1 identifies the disposal and storage options that are under consideration for the SST wastes. The disposal options include leaving the SST structures underground in place at the site. This disposal option for the tank structures could occur with the following contained waste disposal options:

- in-place disposal of ali or part (i.e., partial retrieval) of the contained waste without immobilization

- in-place disposal and immobilization of al1 or part of the contained wastes

- full retrieval of the contained wastes with the tank structures and surrounding contaminated soil left in place

- retrieval and immobilization of wastes followed by re-emplacement of the immobilized waste in underground tank structures

- any combination of these options.

If the tanks are left underground, it is proposed that a protective barrier be placed above the tanks on the ground surface (DOE 1989). The purpose of the protective barrier would be to minimize infiltration of water into the surrounding soil. All of the disposal scenarios listed above would leave voids in the tanks that could allow the tank structure to collapse in future years. If the tank structures did collapse, it could disrupt the protective

(a) Pacific Northwest Laboratory is operated for the U.S. Department of Energy by Battelle Memorial Institute under Contract DE-AC06-76RLO 1830. 


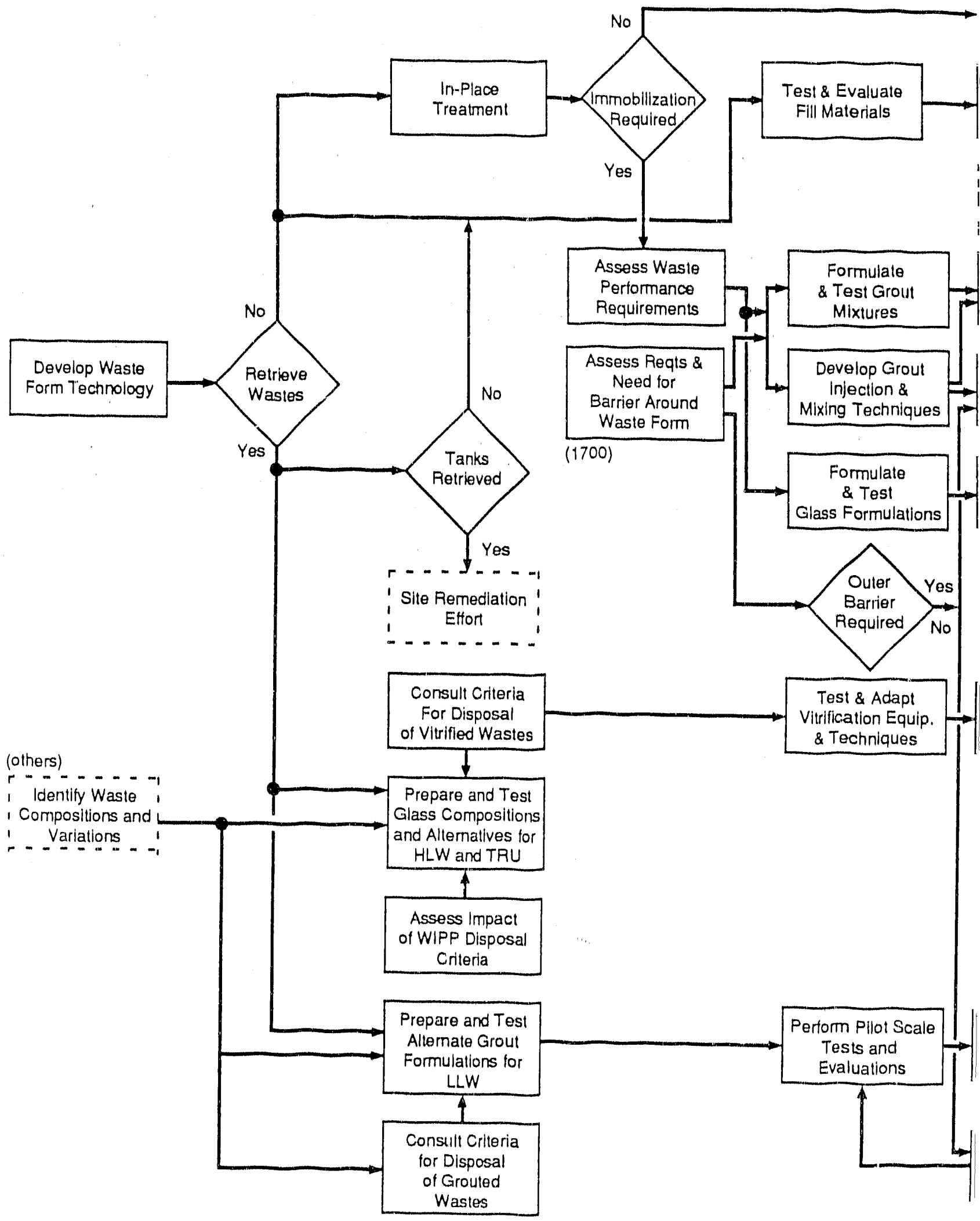

EIGURE 1.1. Disposal and Storage op 

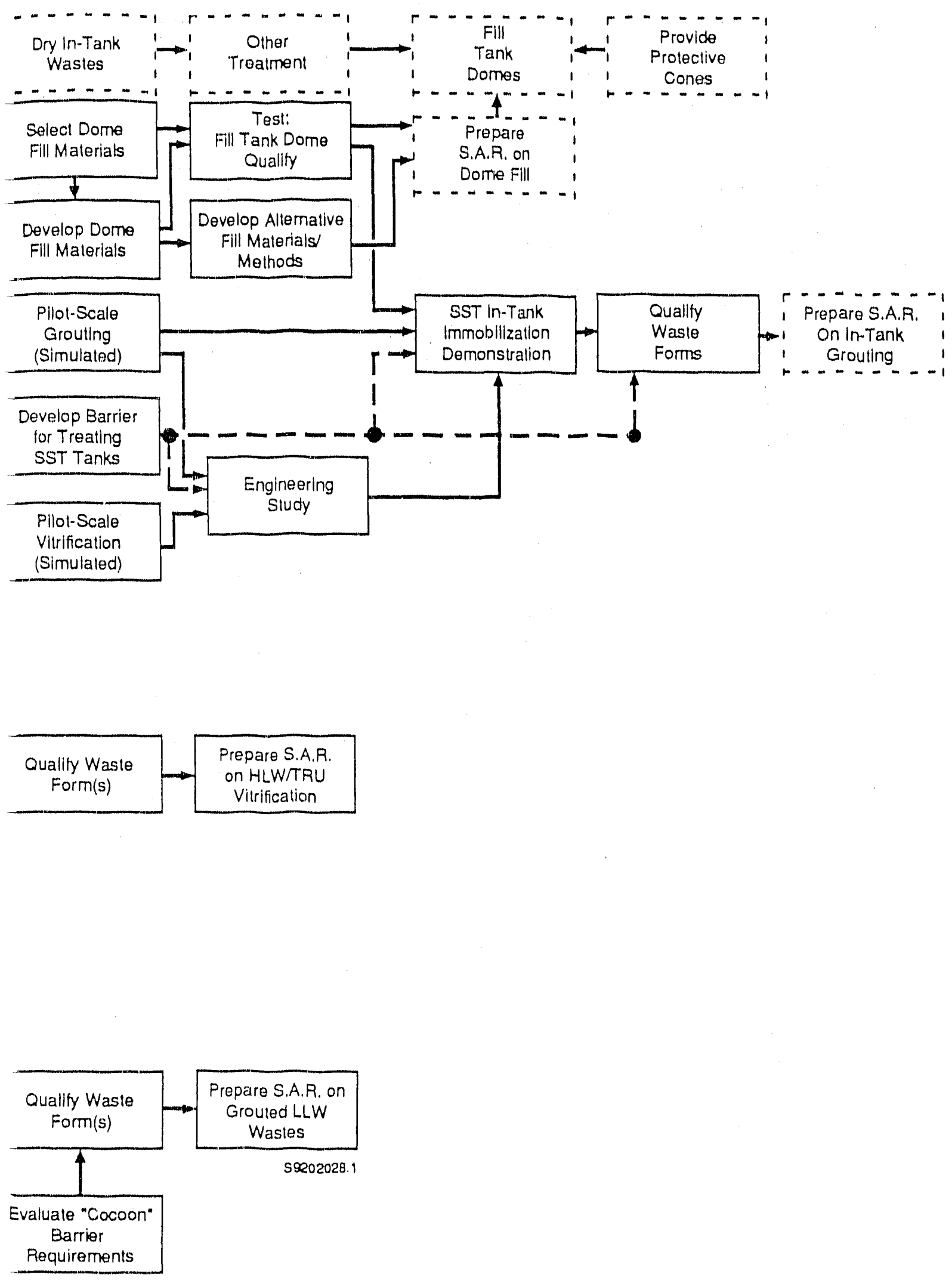

Lions for Single-She 11 Tank Wastes 
barrier and cause it to fail. Therefore, stabilization of the tank structures is required to forestall the potential disruption of the barrier. Filling the voids in the tanks with a suitable material (referred to as "dome-fill" or "fill" in this report) is a method being considered for tank stabilization. The dome-fill task is aimed at developing this technology.

\subsection{THE DOME-FILL TASK}

A total of 149 SSTs were built, placed underground, and used to store radioactive and hazardous waste produced during Hanford Site operations from 1944 unti1 1980. Figure 1.2 shows the locations of the SST farms in the 200 Areas at the Hanford Site. These tanks vary in capacity from 55,000 to 1,000,000 gallons, and each consists of a single steel shell surrounded by reinforced concrete. The SSTs are regulated under the Atomic Energy Act of 1954 (AEA), the Resource Conservation and Recovery Act of 1976 (RCRA), and the Comprehensive Environmental Response, Compensation, and Liability Act of 1980 (CERCLA). Therefore, regulation efforts are shared by the DOE for radioactive constituents under the AEA, the state of Washingtion and the U.S. Environmental Protection Agency (EPA) for the hazardous wastes under RCRA, and the EPA for hazardous wastes under CERCLA. The Hanford Federal Facility Agreement and Consent Order (WDOE, EPA, and DOE 1989) specifically identified the waste contained in the SSTs as being regulated by RCRA under the Corrective Action Measures with the Washington Department of Ecology (Ecology) as the lead agency.

The development of dome-fi:l technology is one part of the corrective action measures undertaken as a result of the consent order. As shown in Figure 1.3, the dome-fill task is a comprehensive, multiyear effort. The task has two main purposes:

- identify dome-fill materials to stabilize the tank structures and prevent collapse of the tanks' dome

- develop the technology and methods required to fill the tanks with the selected material. 


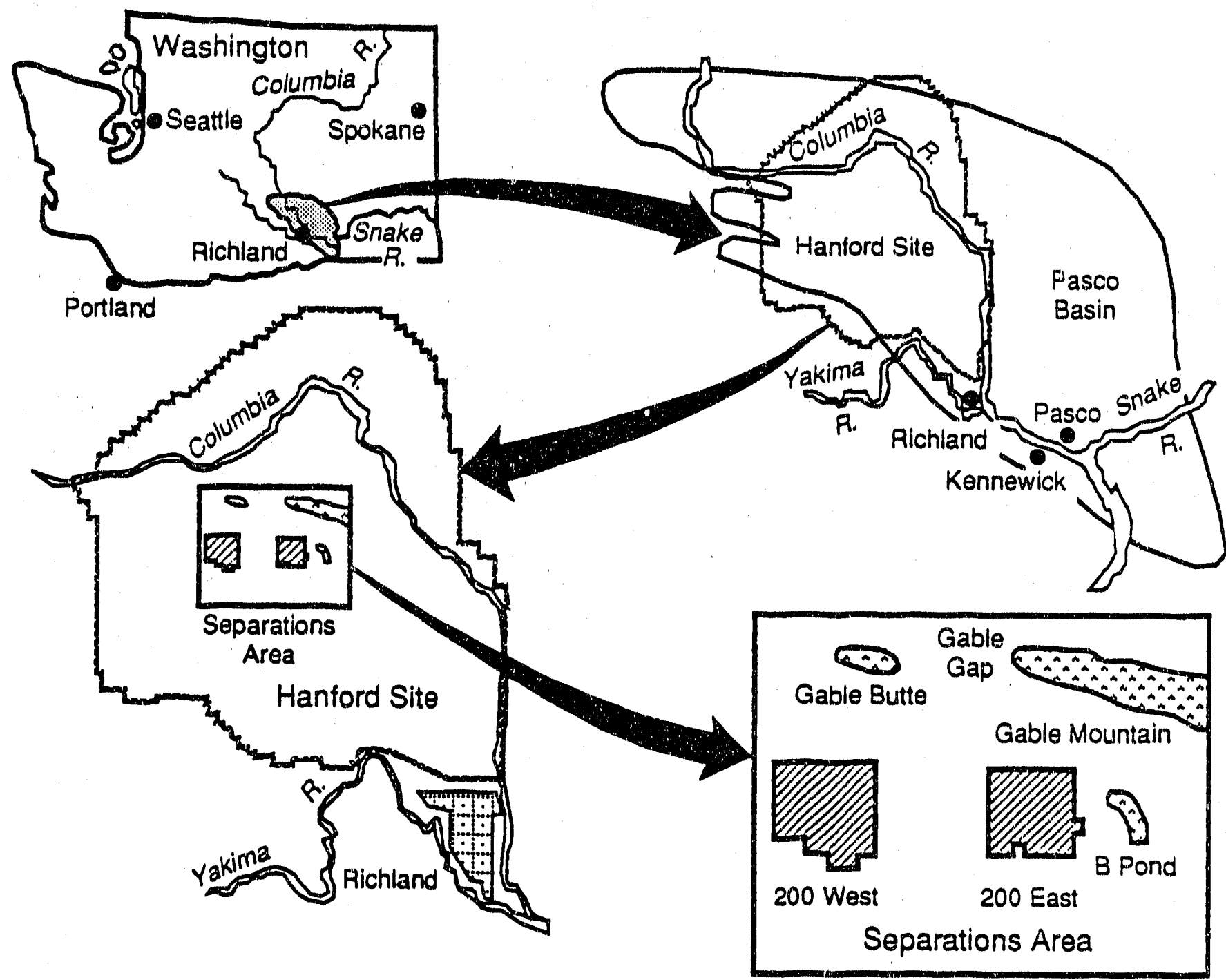

FIGURE 1.2. Locations of the Hanford Site and the Separations Areas

Initially, this task involved a review of the past dome-fill work at the Hanford Site arid other pertinent literature. This review was intended to establish a baseline for the dome-fill effort and to provide dome-fill information as a basis for continuing efforts. This baseline information will be used in future work to aid in selecting candidate and alternative fill materials and methods, as well as developing and testing the appropriate technology for filling the tanks. The dome-fill task efforts will ultimately contribute to the development. of an SST disposal plan. 


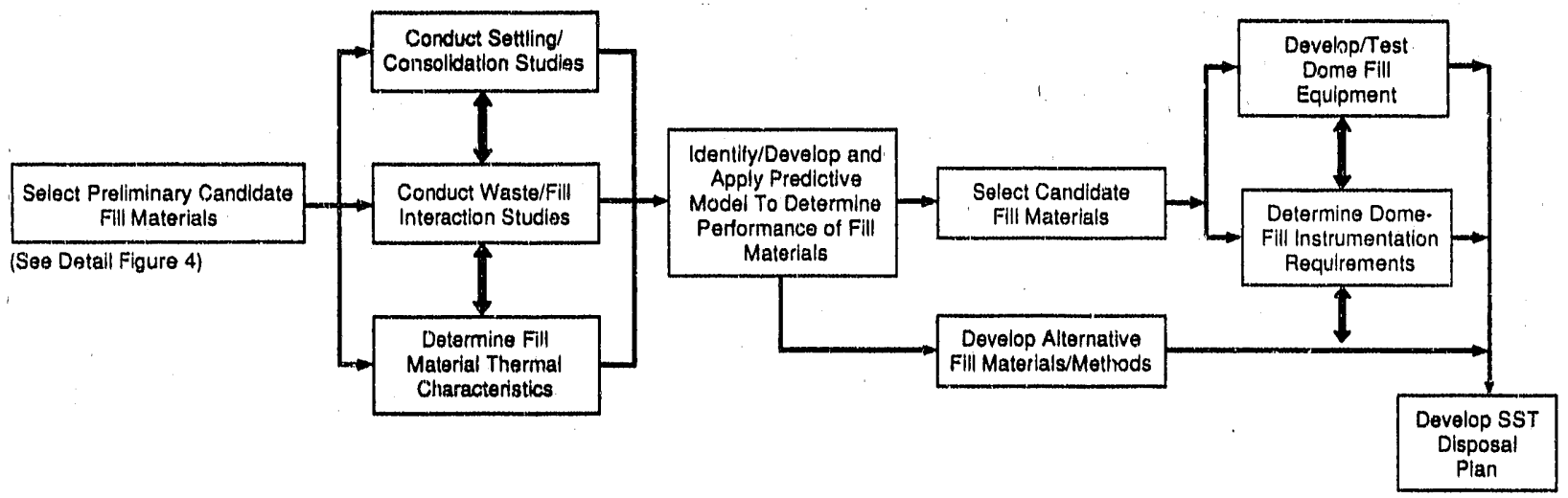

FIGURE 1.3. Dome-Fil1 Technology Development

The structure of the present study is illustrated in Figure 1.4. The purpose of the study was to as: is current dome-fill technology by reviewing past eiforts and performing a literature review. The assessment was then used to help identify existing dome-fill technology, preliminary performance criterid for the dome-fill technology development, potential testing strategies, and potential fill materials. The potential fill materials were then qualitatively evaluated and a list of preliminary candidate fill materials identified. This list of materials will be used in the initial thermal and structural testing phase.

\subsection{OVERVIEW OF REPORT}

The remainder of this report is organized into four major sections. Section 2 provides the major conclusions drawn from this study, on the existing dome-fill technology assessment and on the recommended scope of future efforts. In Section 3, previous dome-fill studies conducted by PNL and WHC are reviewed in chronological order to set the background for the dome-fill task. The preliminary external criteria (i.e., regulatory demands and barrier design) and internal criteria (i.e., SST chemical erivironment and structural integrity) that will be required to determine the performance criteria required for the dome-fill materials and technology development are identified in Section 4. Because the waste composition varies in the SSTs, it is possible that there will be several different dome-fill scenarios and that each 


\section{Select Preliminary Candidate Fill Materials}

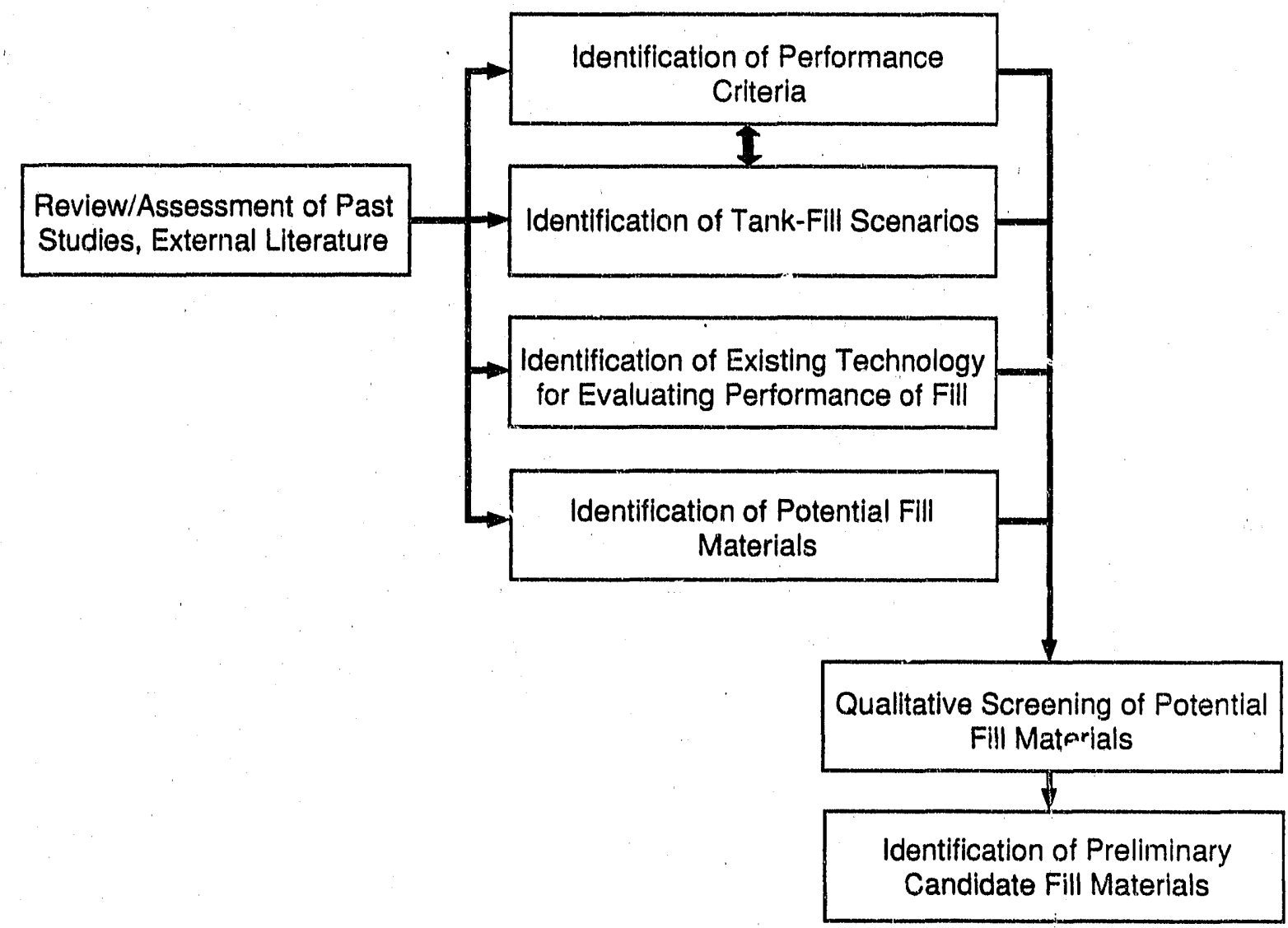

FIGURE 1.4. Dome-Fill Technology Assessment and Selection or Preliminary Candidate Fill Materials

may have different fill-material requirements. Section 4 identifies how these potential dome-fill scenarios may allow the tanks to be grouped into a few categories based on the interrelated functions of waste type and quantity, iiquid content, and tank design. The approach to evaluating the structural integrity of the SSTs is also assessed.

In Section 5, the identification of preliminary candidate fill materials is discussed. Physical, chemical, economic, and other attributes (e.g., special transportation and handling constraints) of fill materials that determine the preliminary screening criteria are discussed. The primary selection 
criteria are identified, and a list of proposed testing approaches as well as a preliminary list of dome-fill materials are presented. 


\subsection{CONCLUSIONS}

This section describes the conclusions of the existing dome-fili technology assessment as well as the conclusions concerning the recommended scope of future efforts. The background of the technology assessment conclusions is discussed in Section 3, which identifies the baseline of technology development. The background of the scoping conclusions is discussed in Sections 4 and 5 . Section 4 identifies issues that will affect future technology development, and the scope of future efforts is identified in Section 5.

\subsection{DOME-FILL TECHNOLOGY ASSESSMENT}

In the past, the dome-fill technology assessment work has emphasized the exclusive use of basalt gravel as the fill material. Significant efforts have been made to develop procedures and the necessary equipment for filling the candidate SSTs with basalt and allowing the fill material to consolidate over time. A centrifugal thrower was also tested for distributing basalt gravel in a mock-up tank facility. Preliminary investigations of safety and health issues involved in filling the domes of the SSTs have been conducted.

However, alternative materials to basalt have not been adequately considered. Paper studies were used to select basalt as the primary candidate fill material, and technology development work to date has focused almost exclusively on basalt. Insufficient data exist on other fill materials to determine whether basalt is, in fact, the preferred fill material. Although preliminary testing indicates that basalt may react with waste similar to that contained in the SSTs and, subsequently, dissolve in it, the existing data are insufficient to determine key reaction parameters, such as the rate and extent of the reaction.

\subsection{SCOPINE STUDIES}

Four distinct dome-fill scenarios have been identified. The SSTs, along with their contained wastes, may ur may not be immobilized prior to domefilling. Therefore, the dome-fill technology may be used for SSTs 1) that have had their wastes fully retrieved and that have been cleaned, 2) that have 
had all or some of their wastes retrieved and that have been immobilized, 3) that contain all or some of their wastes and that have not been immobilized, and 4) that have had all of their wastes immobilized in place.

The regulatory driver for dome-fill technology is the closure of the single-shell tank structures as RCRA landfills. RCRA landfill closure requirements include ensuring that the cover is stable and that subsidence will not adversely affect its integrity, so the primary performance standard for dome-fill is the protective barriers' designed allowable subsidence.

The size and shape of the SSTs may also determine modes of structural failure and the requirements of the fill material. SST waste composition is another uncertainty and can vary from tank to tank, so different fill materials may be necessary for different waste compositions.

Other characteristics of fill materials include the following:

- physical properties such as compressive strength, thermal characteristics, and bulk density

- chemical properties such as solubility and reactivity (rate and extent) with water and SST wastes and the properties of the final reaction products

- the final consolidation of the mixture of fill and waste

- economic factors including cost, transportation, and handling requirements.

To determine the suitability of candidate fill materials, chemical reactivity/durability and material compaction tests (with and without SST wastes) will be performed on them. Based on the preliminary screening study conducted this year, the following list of candidate fill-materials has been compiled for further testing:

- silicates such as basalt, gneiss, bentonite, and phosphates such as apatite

- carbonates such as calcite and dolomite (which may be used in combination with absorbent materials such as zeolites, gibbsite, and clays) 
- oxides such as magnetite, hematite, and rutile (although these materials have to be tested further for the consolidation of the waste-fill mixture, since they are comparatively heavier than the known waste density)

- other composites or mixtures of materials such as grout mixtures (cement-slag-clay) and other mixtures with concrete, clay, and zeolites. Synthetic materials such as ceramics will also be considered. 


\subsection{REVIEW OF PRE IOUS DOME-FILL STUDIES}

Dome-fill technology development activities, planning documents, formal reviews, and proposals have been generated at Hanford since 1985. At that time, DOE directed Rockwe11 Hanford Operations (RHO) to prepare a plan for demonstrating techniques that potentially could be usud for the disposal of the SSTs. Progress was made in planning done-fill technology approaches and in some preliminary laboratory testing and technology development. However, the current status of dome-fill technology at Hanford has never been summarized and assessed.

This section summarizes and reviews previous studies and planning efforts related to the development of the dome-fill concept for the SSTs at Hanford. It includes a discussion of the original concept of dome-fill technology and the subsequent development of fill methodology and material. Past technical efforts are discussed and summarized, and proposed modifications to the original SST dome-fill efforts are identified. This review of dome-fill technology development for the SSTs that occurred through 1989 will serve as a baseline for future dome-fill technology development.

\subsection{DEVELOPMENT OF THE DOME-FILL CONCEPT}

Historicaliy, in situ isolation of underground SSTs has been considered as one of the possible alternatives for disposal of the SSTS and the wastes they contain. This disposal alternative was based on the assumption that migration of the wastes contained within the tank structures could be prevented by isolating the tanks from the surrounding environment. The two methods considered for isolating the tanks were to enclose the tank structures with in an impermeable barrier or to stabilize the waste in place and then place a protective barrier above the tanks.

Initial technology efforts designed to achieve in situ disposal of the SSTs and their contained wastes focused on isolating the tanks by using an impermeable barrier surrounding the tank. An early study by Wiater and Higley (1977) examined the feasibility of surrounding a small underground tank with a sodium silicate-based grout as a way to isolate the structure. This attempt 
was unsuccessful, in part, because there were grout injection problems related both to emplacement techniques and to the highly variable vertical and lateral changes in sediment character surrounding the tank. Subsequentiy, the alternative of isolating the tanks by stabilizing or immobilizing the wastes and placing a protective barrier above the SSTs was considered.

One of the ways that the protective barrier could fail was by subsidence of the underlying soil. Because the SSTs are only partialiy filled with wastes (Winters et a1. 1989), they contain voids into which the tank structures could collapse. Filling the voids in the tanks with a chemically and physically stable material was considered as a potential way to minimize the impact of structural failure of the SSTs and, therefore, the subsidence of the protective barrier.

\subsubsection{Development of Criteria for Candidate Dome-Fill Tanks}

Because of the varying composition and volume of the waste and its possible interactions with other materials, it was assumed that not all of the SSTs would be amenable to dome-filling. Consequently, the original concept of dome-fill was considered to be an option only for those tanks that contained stabilized wastes. The tanks generally contain salt cake derived from partial evaporation of the stored sludge. Residual liquids are removed by constructing a well in the salt cake. According to Metz and Ogren (1976), a tank is stabilized when all the residual surface liquid from the salt cake is removed and when the salt well inflow rate of the residual liquid is less than the pumping rate. Thus, both sludge (and/or salt cake) and liquid can exist in a tank even after stabilization. By requiring that only domes of stabilized tanks be filled, the intent was to perform dome-fill only on tanks containing somewhat amenable waste forms. However, the implicit assumption was that the wastes contained in the tanks could be readily characterized and, thus, tanks suitable for dome-filling identified.

In order to select tanks that could be used in developing and testing the dome-fill technology, generalized performance criteria for tank acceptability and dome fill material were developed by Weiss (1986). The original criteria established were that a suitable tank would have the following waste characteristics: 
- transuranic (TRU) inventory of less than $100 \mathrm{Ci}$

- organic complexant concentration less than $0.1 \%$ by weight

- heat generation rate of less than $15,000 \mathrm{Btu} / \mathrm{h}$

- waste volume less than the void volume (i.e., volume to be filled) required to fill the tank to nominal capacity.

\subsubsection{Dome-Fill Technology Development and Planning}

Following the selection of the tanks in the 241-TY farm for the development and testing of dome-fill technology, efforts began to focus on developing design and performance criteria for dome-fi11 materials (Flyckt 1985; Carlson and McBeath 1986). Flyckt (1985) identified design criteria for demonstrating dome-filling techniques at the 241-TY tank farms. Flyckt's document included a discussion of the equipment and facilities required to prepare the tank farm, acquire the fill material storage and handling equipment, and install the monitoring system. At that time, the recommended material for dome-fill was basalt gravel. A commercially available centrifugal thrower was recommended for distributing the basalt gravel within a tank.

The dome-fil1 technology plan developed by Carlson and McBeath (1986) elaborated on the objectives for developing dome-fill technology that were specified in Flyckt (1985); Carlson and McBeath's plan also described general performance criteria and the tasks required to close the dome-fill issue. To prevent subsidence of the procective barrier, Carlson and McBeath noted that the fill-material must meet the design requirements of being placed to the haunch of each tank and remaining stable over the 10,000-year design life of the system. Based on these design requirements, they identified some of the performance standards that the candidate dome-fill materials should have, including the following:

- physical and chemical stability to prevent subsidence and subsequent destruction of barrier material

- ability to provide pore spaces to make it possible to leave some waste in the tanks and to allow pressure equalization within the tanks after filling

- ability to be placed within the tanks to prevent subsidence of barrier material due to inadequate backfilling. 
The following required tasks were identified by Carlson and McBeath in the 1986 technology development plan:

- conceptuar model development

- waste/fill chemical interactions development

- waste/fill physical interactions development

- fill equipment development

- final tank closure development

- field monitoring and instrument development

- single-shell tank dome-fill field test development

- final SST disposal planning development.

With the development of these tasks in the technology plan, preliminary analyses of waste/fill interactions were performed. The initial laboratory studies evaluated the suitability of the basalt gravel as a fill material.

\subsubsection{Laboratory Studies of Basalt/Waste Interactions}

Because the composition of the SST waste is variable and uncertain, a wide array of potential waste/fill material interaciions could occur. Adams et a1. (1987) identified 27 different waste types that may have to be considered in evaluating dome-fill material and waste interactions. However, for screening studies, the effect of only three waste types representing expected SST waste compositional ranges were used (Risenmay 1986). Risenmay conducted compaction and consolidation tests using REDOX process wastes, PUREX process wastes, and bismuth-phosphate wastes. Each type of waste has a range of compositions, but all are high-nitrate salts and they have a high-alkali hydroxide component in common, a's do all the SST waste sludges.

As previously noted, initial planning documents focused on the use of basalt gravel as a dome-fill material. Crushed basalt was proposed as a suitable dome-fill material because it was readily available at a low cost. A possible problem was dissolution of basalt in the highly caustic wastes leading to development of excessive voids in the tanks. This problem was recognized in a preliminary literature review investigating possible basalt 
dissolution (Routson 1983), but the reviewers felt that if basalt particle sizes were large enough, the effect on consolidation would be minimal. Subsequent1y, PNL researchers conducted a laboratory screening study on the chemical stability of basalt in synthetic SST wastes.

The screening study determined the short-term and long-term reaction of Pomona basalt with two synthetic wastes, a bismuth-phosphate waste and a REDOX waste. Waste sludges were prepared from formulations derived from the TRAC code predictions. Bismuth-phosphate waste consists prinarily of $\mathrm{BiPO}_{4}$, $\mathrm{FeO}(\mathrm{OH}), \mathrm{NaNO}_{3}$, and $\mathrm{Na}_{2} \mathrm{SiO}_{3}$; REDOX waste is similar but with $\mathrm{Al}(\mathrm{OH})_{3}$ in place. of $\mathrm{BiPO}_{4}$. Both wastes have $\mathrm{pH}$ values of 12 . The sludges prepared for these screening tests contained about $70 \%$ water and had a pudding-like consistency.

Two thermal analysis methods were used to examine the short-term reactions between the waste and basalt sand, namely the thermogravimetry (TG) and differential scanning calorimetry (DSC) methods. These methods were tested at temperatures up to $250^{\circ} \mathrm{C}$ and have the potential to detect decomposition reactions of hydrated compounds, free water boil-off, ion exchange, and oxidation by nitrate. The long-term reactions were determined by placing either basalt sand or basalt coupons in the waste for up to 280 days at temperatures between $20^{\circ} \mathrm{C}$ and $104^{\circ} \mathrm{C}$. At the end of the experiment, the waste was analyzed for basalt components and the basalt coupons were analyzed by scanning electron microscopy (SEM) with energy dispersive $x$-ray analysis (EDAX).

The short-term thermoanalytical experiments indicated no significant reactions between the waste and basalt. Loss of water was the only major reaction noted up to $250^{\circ} \mathrm{C}$, and the loss was due almost entirely to the waste dehydration. In contrast, the long-term experiments showed significant basalt attack and dissolution with both types of waste. The bismuth-phosphate waste was slightiy more aggressive than the REDOX waste, but after 280 days and at $100^{\circ} \mathrm{C}$, the degree of attack was similar. Based on weight loss measurements, the basalt was estimated to lose about 5 wt\% per year. Basalt consists of small crystals embedded in a glassy matrix. The initial attack was a dissolution of the glassy matrix followed by attack on the more calcium-rich plagioclase (sodium-calcium aluminosilicate). 


\subsubsection{Summary of the Initial Dome-Fill Effort}

Although the basalt chemical durabtlity studies suggested that basalt may not be satisfactory in all cases, insufficient data were avallable to make long-term predictions of the basalt's chemical durability. To assess the implications of the initial findings, the dome-fill technology developmert plan was reviewed. The review dealt with possible revisions to the $1986 \mathrm{plan}$ and considerations of other dome-fill materials.

Reviewers' comments concerning the original dome-fill technology deve1opment plan included discussion of the material selection process, laboratory analysis methods, dome-fill material performance criteria, and planning methods. Specific comments included the following:

- the plan did not allow enough effort for screening materials other than basalt

- selection should be based on kine ic studies and reaction limits of materials in waste sludges, not on coupon weight changes

- long-term laboratory tests should be descoped in favor of shorterterm tests

- real tank waste should be tested earlier

- better criteria for dome-fill material performance need to be established

- the assumption that selection of dome-fill material and dome-fill equipment can proceed in parallel is false.

Following the review, PNL was asked to submit proposals for evaluating and selecting dome-fill materials.

\subsection{PROPOSALS FOR SELECTING AND EVALUATING DOME-FILL MATERIALS}

PNL developed and submitted proposal outlines for identifying dome-fill materials between 1986 and 1988. These proposals were for work to determine the optimum fill materials and to obtain sufficient data to develop a kinetic model for dome-fill durability. Although not funded, the proposals furthered 
the development of dome-fi11 technology by identffying new testing methods for evaluating dome-fill materials, criteria for material selection, and a preliminary 1 ist of potential fill materials.

The proposed approach was to identify candidate matertals from the 1tterature and to conduct a screening study involving accelerated testing concepts. The accelerated testing approach was based on utflizing high surfacearea-to-volume test configurations and elevated temperatures. The selected candidate materials would be subjected to more detailed testing and property measuranent to determine their sultabllity for fllling the SST volds. A limited effort was also proposed for investigating the usa of mixed materials for dome filling. Subsections 3.2.1 through 3.2.3 summarize the main details of the proposals.

\subsubsection{Material Selection Criteria}

Two important properties that were identified for dome-fill materials were low reactivity in high $\mathrm{pH}$ environments and high compressive strength, particularly after interacting with high $\mathrm{pH}$ environments. The criteria for fill materials also included the maximum amount of material/waste interaction that could be tolerated without causing extensive fill consolidation and subsequent loss of barrier integrity due to slumping. A preliminary list of candidate materials was established from the literature, using high $\mathrm{pH}$ environment behavior and properties as the criteria. It was proposed that the preliminary list could be reduced on the basis of material cost and availability.

\subsubsection{Screening/Selection Methodology}

The preliminary material screening suggested that it would be beneficial to conduct accelerated material/waste reactivity tests at elevated temperatures and at high surface-area-to-volume ratios for short time periods. Reactivity would be determined by solution analysis, x-ray diffraction (XRD), and thermogravimetric analysis (TGA), along with SEM analysis. It was also proposed that the compressive strengths of reacted material would be determined. A test matrix including candidate materials and a number of waste types would be developed. The best three to five fill materials based on the degree and 
type of reaction would be selected for a longer-term study. An initial interpretation of the reaction mechanisms would then be used to design ionger-term tests.

\subsubsection{Einal Selection and Evaluation}

Proposals for final selection of dome-fill materials emphasized longterm kinetic studies at several temperatures to determine overall reaction order, obtain a generalized rate law, determine the degree of reactivity, and evaluate how material/waste reactions affect physical properties such as compressive strength. The proposals suggested that materials showing order-ofmagnitude improvement in compressive strength over basalt should be considered at this point. Material mixtures (for example, basalt-grout) were also proposed to be considered. The longer-term tests were to include autoclave equipment with direct sampling capability at pressure and fairly large volumes. In a high-salt system at elevated temperature, direct solution capability was identified to be necessary at times to prevent precipitation during sampling.

\subsection{DEVELOPMENT OF A REVISED DOME-FILL TECHNOLOGY PLAN}

Following the review of the original dome-fill technology development plan (Carlson and McBeath 1986) and consideration of the dome-fill proposals developed by PNL, a revised dome-fill technology plan was developed (Adams et a1. 1987). This plan included an evaluation of dome-fill materials and equipment that involved boich laboratory and field testing. In the revised plan, the researchers felt that the key problem in dome-filling was to determine how much the voids in and above the waste could be reduced to prevent the tank structure from collapsing. It was recommended that this be evaluated on a tank-by-tank basis. Further, the plan noted that the amount of allowable collapse of the tank structure must be within the limits of allowable barrier settlement. Ful1-scale engineering tests on actual waste tanks in the 241-TY tank farm would be required to complete the technology development.

At the time the technology plan was prepared, a waste tank mock-up facility had been constructed to test dome-filling equipment (Powers 1988). A centrifugal thrower to be used for gravel placement in the tanks was purchased 
and tested in the mock-up tank facility. The thrower was tested for gravelthrowing distances and trajectories. Shadowing effects from in-tank obstructions and instruments were also determined. Other design parameters that were tested included abrasion rates of the basalt gravel on equipment, the optimum feed rate of the basalt gravel to the centrifugal thrower, and determination of dust-generation data for use in sizing a filter system.

The technology plan identified the following technical tasks as being required to develop and test the dome-fill technology:

- criteria and standards development

- evaluation of dome-fill alternatives

- dome-fill settlement evaluation

- fill material analysis

- dome-firr test development.

This section briefly describes the scope and objectives of each task.

\subsubsection{Criteria and Standards Development}

This task was to obtain data from the barrier development program in order to develop standards for the amount of barrier settlement that could be tolerated without destroying the barrier's integrity. The information would then be compared with the dome-fill consolidation data and models to evaluate the allowable amount of waste-fill settlement in each tank.

\subsubsection{Evaluation of Dome-Fill Alternatives}

This task was developed to evaluate alternatives to 100 se, natural materials as dome-fill candidates on a level-of-effort basis. Alternatives were to include man-made synthetics, uncommon natural materials, or recently developed sorbent and structural materials.

\subsubsection{Dome-Fill Settlement Evaluation}

This task dealt with three questions. First the extent and consequence of vapor-phase movement to the hygroscopic wastes was to be determined. It was hypothesized that if the wastes were wetted sufficiently, the fill materials might settle to the bottom creating voids between the fill and dome. 
Next, the longevity of tank concretes was to be evaluated, based in part on knowledge of ancient concretes. Finally, the task would have provided a mathematical model for predicting waste-fil1-barrier consolidation and settlement for comparison with the barrier settlement standard.

\subsubsection{Fill Material Analysis}

This task consisted of subtasks that included screening and selecting dome-fill materials, definition of waste types, definition of appropriate tests, and testing fill-waste mixtures. A study was to be prepared to formalize the selection of candidate fill materials. The task also included waste type definition and prioritization of reactive components along with comparative chemical reaction tests to evaluate waste consolidation and waste-fill settlement.

A series of solubility and reaction-rate screening studies was to be performed on the candidate fill materials to select the best materials. Those selected would have been evaluated further to determine reaction mechanisms and reaction products. Reaction product studies would include a series of physical and chemical property tests performed after waste-fill reaction has occurred.

In parallel with the solubility and reaction-rate studies, a series of synthetic and actual waste physical property iests was to be conducted. These tests included laboratory consolidation, shear strength, permeability, liquid and plastic properties tests nn synthetic wastes and confirmation tests on actual wastes. These data would be used to help calculate waste-fill consolidation and settlement.

\subsubsection{Dome-Fil1 Test Development}

This task involved an initial test of dome-fill techniques in the 241-TY tank farm in the 200 West Area. The task's purpose was to test fill equipment, especially the centrifugal thrower and thrower support. The task would have been conducted in parallel with the other tasks on the assumption that basalt would be a satisfactory fill material for the 241-TY farm, but would not necessarily be suitable for other tanks. This was essentialiy a demonstration task to show that the SST voids could be filled safely and to confirm 
operational and safety procedures. This task was also intended to confirm the cost and schedule estimates for dome-filling.

\subsubsection{Results of the Revised Dome-Fill Technology Plan}

The revised dome-fill technology plan was developed by incorporating the reviewers' comments to the original plan and the scopes of the PNL proposals developed subsequentily. This revised plan will form the basis for the technical approach to the present dome-fill study and the development of test procedures.

\subsection{SUMMARY OF HANFORD DOME-FILL. TECHNOLOGY HISTORY}

Although considerable effort was spent to develop dome-fill technology pians and approdches, the actual development effort was halted shortly after preliminary laboratory tests showed that basalt may dissolve. However, the planning efforts and limited analytical work are of benefit to the current dome-fill technology development effort. The experience will allow the refinement of the fill-material evaluation process and equipment design and testing efforts. Sections 4 and 5 of this report discuss the relationship of these issues to the current dome-fill effort in more detail. 


\subsection{DOME-FILL TECHNOLOGY ISS'JES}

This section defines the baseline of the currant dome-fill technology task. The baseline is described in terms of the issues influencing the domefill technology development, as determined from the review of past work in Section 3. The issues include dome-fill technology performance requirements, dome-fill scenarios, and projects of developing technologies that must interact with dome-fill operations. This section also ties tognther the previous developments reviewed in Section 3 to the discussion of preliminary dome-fill candidate materials in Section 5 .

\subsection{IDENTIFICATION OF THE DOME-FILL PERFORMANCE STANDARD}

The incentive for developing dome-fill technology is the possibility that the SST structures could be allowed to stay in place underground, over the period of time required for closure (i.e., 10,000 years). In order for the tank structures to be left underground, they must not adversely affect the performance of the protective barrier to be emplaced above. Therefore, the dome-fill technology effort is intended to prevent the failure of the protective barrier by subsidence resulting from the structural failure of the SSTs.

The primary performance standard imposed on dome-fill technology is that the allowed slump, or collapse of the tanks' structures, must be less than the amount of subsidence that will cause the protective barrier to fail. Secondary performance standards include the ability to reduce the potential for migration of the waste constituent to the surface and to inhibit water and plant intrusion. If the SST structures are left in place, RCRA closure or post-closure requirements may be similar to those placed on a 1 andfil1. Specific landfill closure requirements as specified by RCRA that pertain to the dome-fill task include the mandate that final design and construction of a protective barrier must accommodate the subsidence and settiing so that the barrier's integrity is maintained (Keller et al. 1989). Barrier design, therefore, is an integral aspect of dome-fill technology requirements. 


\subsubsection{Barrier Design}

Planning and development of Hanford's protective barriers is being done by the Hanford Site Protective Barrier Development Team (Westinghouse 1990). Development of the protective barriers' performance standards, including allowable barrier subsidence, is the responsibility of this team. Allowable subsidence standards for the protective barrier system have not been specified or developed yet.

As identified above, the allowable subsidence of the protective barrier system is the primary performance standard for the development of dome-fi11 technology. The specification of these limits are the key and necessary components for the timely development of the dome-fill technology. Based on the 1989 dome-fill task technology development plan (Klel et al. 1990), these specifications will be required for the evaluation of dome-fill materials by fiscal year 1992 .

\subsubsection{Barrier Subsidence}

Determining the amount of barrier subsidence that results from a collapse of the tanks' domes is a complex problem. Initially it will be assumed that the collapse of the domes will directly affect the protective barrier. Therefore, if the tanks' domes collapse by $25 \mathrm{~cm}$, then the resulting barrier subsidence will also be $25 \mathrm{~cm}$. The problem of tank structural failure and the effect on subsidence is discussed in more detail later in this section.

\subsection{DOME-FILL SCENARIOS}

As noted in Section 3, doine-fill technology was originally intended to be applied only to tanks with stabilized waste left in place. However, the current concept of dome-fill technology broadens its application to tanks with retrieved waste and to tanks with all or part of their wastes in place and possibly immobilized. The requirements for the dome-fill material will become more rigorous as the waste becomes less treated.

The simplest dome-fill case, in terms of requirements imposed on fill materials, is a tank with its waste fully retrieved. In this case, the fill 
material can be evaluated solely on its structural properties (e.g., compressive strength, consolidation, compaction). Conversely, the most complex dome-fil1 case will be a tank with its waste left in place, without any immobilization effort. In addition to its structural properties, the fill material must then be evaluated on the rate and extent of its reaction with the waste. The structural properties of the fill material will probably be modified by its reaction with the waste contained in the tanks. Further, as noted in Section 3, the waste composition in each tank is uncertain and varies from tank to tank.

Fortunately, the two factors that are most important in determining how the dome-fill material will react to wastes that are left in place are the $\mathrm{pH}$ and volume of liquid left in tne tank. These two parameters appear to be fairly well characterized in the SSTs (Winters et a1. 1989). An effort to group the tanks according to their 1 iquid $\mathrm{pH}$ and volume will be performed next year. This information will be used to help design laboratory testing. The most stringent dome-fill scenario (i.e., wastes left in place, with no treatment) will be used initially to evaluate and screen candidate dome-fill materials. This scenario is discussed in more detail in Section 5.

Another possible factor for determining dome-fill material requirements is the geometric shape of the SST structures and the relationship of that shape to determining the tank structure's failure modes.

\subsubsection{SST Designs}

The SSTs are all constructed of reinforced concrete shells with nonstress-relieved steel liners (ASTM A283 Grade C or ASTM A201 Grade C carbon steel) on the sides and bottom. The tanks have four basic geometric shapes (Figure 4.1) with capacities ranging from 55,000 to 1,000,000 gallons. Because the tanks differ in shape and size, the stresses on the tanks will vary in magnitude and location. It is logical to assume that the tanks will a] so fail structurally in different locations because of the different stresses. Therefore, the structural support that the fill material will be required to provide for the tank will also depend on the size and shape of the tank. 

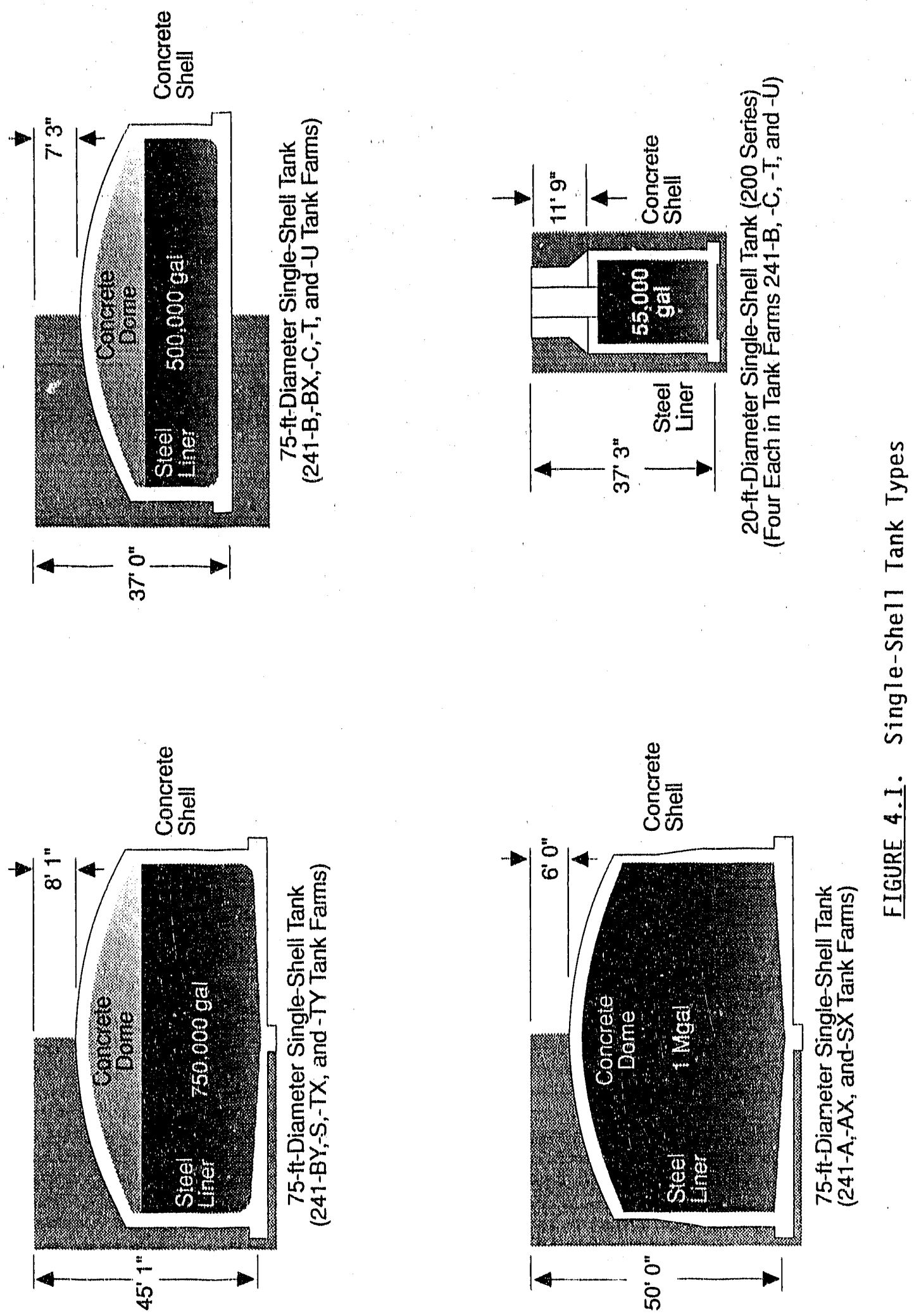

4.4 
Preliminary assessment of the tanks' structural fatlure has identified the collapse of the dome structures and the tanks' footings or walls as the two most 11kely modes. In both cases, the load would be transferred to the fill material. The compressive strength of the fill material will determine its ability to withstand deformation after the sudden loading. After the transfer of the load, consolidation and settling of the fl11 matertal over time will become important.

\subsection{RELATIONSHIP TO OTHER TECHNOLOGY DEVELOPMENT PROGRAMS}

There are parallel technology development projects under way that will require interfacing at some point. One of the major technology development projects under way that may affect the develupment of the dome-fill task is the protective barriers development project. The interrelationship of the dome-fill task and the protective barriers project has been discussed previousiy. The important issue is the development and specification of allowable subsidence for the protective barrier. Communication between the protective barriers development team and the dome-fill technology team is important to ensure that realistic specifications for allowable subsidence are developed. Informal communications between the two groups already begun. Further development of working communications is planned. 


\subsection{PRELIMINARY SELECTION OF DOME-FILL MATERIALS}

This section deals with some of the selection criteria and methods of identifying a preliminary list of candidate dome-fill materials for in situ disposal of the SSTs. Once the selection criterla and an initial list of fill materials are complled, the candidate materials will be screened using a matrix consisting of the material properties and the criteria. A collection of the fill materials that satisfy most of the criteria will yield the preliminary list of dome-fill materials that is shown at the end of this section. Additional procedures to further screen the preliminary 1 ist will be designed to determine the interactions of the candidate f 111 materials with simulated and actual SST waste.

Although dome-fill technology is being developed for a variety of SST disposal options (i.e., partialiy and fully retrieved tanks as well as in-place tank wastes), the initial general fill-material requirements considered will focus on in-place disposal of contained SST wastes. Tanks disposed of $i n-p l a c e$ with their contained wastes are assumed to be the most restrictive case in terms of f111-material performance requirements. Under this assumption, the general requirements for the fill-material include the following considerations:

- The material should settle slowly to the bottom of the tank.

- As the fill material settles, the waste should fill the interstitial spaces between the fill fragments, not float on top of the fill nlaterial or be displaced suddenly after the filling operation.

- The material should not react adversely with the tank contents and generate water, noxious or explosive gases, solid or liquid materials known to be complexants for radionuclides, or any other product that may enhance radionuclide transport.

- The material should be a loose material, capable of being distributed evenly within the tanks.

- The material should not have any kinetically significant reactions with the waste material, and any chemical interactions should be within prescribed limits.

- The material should be free of organic contaminants. 
- The material, after emplacement and initial consolidation, should have sufficient compressive strength to $11 \mathrm{~m} / \mathrm{t}$ long-term and secondary settling even if reaction with avallable liquid wastes occurs.

It is expected that subsequent to filling the waste tanks and the domefilling operations, the tank farms will be adequately maintained and monitored for a considerable period of time. The project equipinent for the tank closure operation and the instrumentation system for the monitoring operation will have to be designed to perform their intended function throughout the expected range of Hanford climatological conditions. The in-tank instrumentation and equipment system will be designed to perform even in adverse tank environments including high humidity, high-particulate dust loadings, potentially high radiation zones, and the presence of caustic and/or corrosive materials.

\subsection{PRELIMINARY SELECTION CRITERIA FOR FILL MATERIALS}

This subsection provides a logical sequence of selection criteria for initially screening potential candidates for the dome-fill materials. This screening process will lead to the selection, in the future, of the list of dome-fill materials to be used. The selection criteria are categorized by the physical and chemical properties of the fill material itself and other relevant factors such as the material's availability, cost, rellability, or handling problems. The 1 ist of categories given below may not be all-inclusive, but it should encompass the major qualifications for the overall task. It also does not follow any particular order of importance or ranking, since it is only intended as a mechanism for the first, preliminary screening of the potential candidates.

\subsubsection{Physical Properties}

The physical properties of a candidate fill material include its density (bulk and particle), compressive strength, specific heat, thermal conductivity, and thermal expansion coefficient. In addition to the limiting cases identified in Section 4, the four SST disposal scenarios that will potentially apply to dome-fill techrology include:

- a tank cleaned such that all wastes have been removed, including remediation of the tank structure 
- a tank with contalned waste fully retrieved

- a tank that sti11 has been partially retrieved or left with its contained waste in place

- a tank that contains immobilized waste left in place.

In the first two scerlarios, the fill material will etther fill the entire volume of the tank or at least most of $t \mathrm{t}$. In the third scenario, the fill material may settle slowly to the bottom of the tank. The waste sludge essentially contains clay-sized hydrous oxides, primarily of tron and aluminum. It has a bulk density of approximately $1.6 \mathrm{~g} / \mathrm{cm}^{3}$. Therefore, the $\mathrm{fill}$ material, at least for the third scenario, should have a comparable density $\left(1.4-3.5 \mathrm{~g} / \mathrm{cm}^{3}\right)$ so that the fill material does not settle too rapidly to the bottom of the tank, thereby displacing the sludge and causing it to rise to the top of the tank. The extent of the rise will depend on the amount of interstitial space that is avallable between the segments of the fill material (the material porosity is a different category of the screening criteria and is discussed later). Nevertheless, it is destrable for the fill material to occupy the void above the sludge and not to settle excessively. If excess settling does occur, refilling or topping off may be necessary at a later date to complete the dome stabilization process. For the tank containing immobilized waste (the fourth scenario), the fill material will be required to fill any remaining void space.

The thermal properties of the fill material are important to consider, especially for the third scenar:0. The remaining sludge may still produce heat. If the generated heat is not dissipated well enough, it may have adverse effects on the continued stability of the waste, the fill material, and the surrounding earth. The ability of fill materials to dissipate heat adequately may be an important consideration in the long term.

The inherent stability of the material at high temperatures is also very important. Its thermal conductivity (or its ability to dissipate heat) is especially critical since the fill material may be exposed not only to high temperatures that may result in heat build-up, but also to a high-temperature environment for an extended period of time. Therefore, the characterization 
tests of the f 111 materials will be conducted at three selected temperatures (for example, $50^{\circ}, 90^{\circ}$, and $120^{\circ} \mathrm{C}$ ) over two or three different time periods.

The compressive strength of the material and of the product resulting from the waste/fill material interaction is an important consideration if the impact of the dome collapse at a future date is to be determined. The load in the single-shell tanks filled with a material like basalt gravel is expected to be about $140 \mathrm{kPa}$. If structural fallure (dome collapse) occurs and the sotl overburden settles onto the wastes in the tanks, the total load is expected to rise to $280 \mathrm{kPa}$ (Risenmay 1987). The extent to which the matertal is able to withstand both the basic and the increased impacts without failing would determine the probablitity of any of the sludge exiting the dome opening and/or causing any radiation leaks to the outside.

\subsubsection{Chemical Properties}

In addition to the physical properties of the fill material, its chemical properties are important considerations, especially in the presence of a highly alkaline and reactive environment with or without interstitial liquids (or moisture) in the sludge. The moisture level (or the amount of residual 1lquids) in the wastes may be one of the most important considerations in the choice of an appropriate fill material, since the consolidation of the waste/ fill material product is key to a final tank storage option. Hence the material's solubility, reactivity (or the extent of its reaction with the waste), and any other chemical interaction in the radioactive, wet, and high $\mathrm{pH}$ (alkaline) environments are to be considered. The best fill material would be one that is nonreactive or chemically inert. However, $i^{c}$ the material is reactive (or becomes reactive in the radioactive environment), the extent to which it reacts, the amount of reactivity that can be tolerated, and the final state of the reaction's product and composition are important characteristics. The reaction's end product composition must be stable and have sufficient mechanical strength to help support the tank structure in the event of a dome collapse.

A series of solubility and reaction rate screening studies will be performed on the candidate fill materials to eliminate those materials that have extensive reactions. The remaining candidate materials will be subject to 
further detalled reaction product siudies. The reaction product studies would include a series of physical and chemical property tests to be performed on the wastes and fill materials after they have reacted with each other for an appropriate pertod of time.

In the high $\mathrm{pH}$ environment that exists in the tanks (for example, $\mathrm{pH}$ values greater than 10. [Winters et a1. 1989]), most silica materials are soluble because tonic silica species form from silica-hydroxyl reactions. As hydroxyl tons are consumed, the $\mathrm{pH}$ in the tank is lowered and stlica solubility is reduced considerably. Oxides can also react with hydroxyl ions to form hydrous oxides. Conversely, carbonates are less soluble in a higher pH environment. However, the effects of the other waste constituents on the solubility of the different types of fill materials will require further experimental evaluation.

Some of the waste sludges contain organic complexants or possible complexants, such as ethylene diamine tetra acetic acid (EDTA) and citric acid. These materials are not expected to directly affect the function of dome-fil1 materials. However, complexants can cause some hazardous metals and radionuclides to be retained in the waste liquid rather than be absorbed or precipitated on soils in the event of a tank breach. Thus, a tank (or tank farm) containing large amounts of complexants may require pre-treatment before dome-filling, and furthermore, the chosen fill materials should be compatible with such treatment.

\subsubsection{Predictive Model Development}

A mathematical model will be developed to predict waste/fill material interaction and the rates of consolidation or barrler settlement for SSTs. The model will be based on the results of the preliminary physical and chemical tests performed to characterize the waste/fill interactions. It will incorporate the empirical data gathered from the laboratory and field tests performed on both the waste and fill materials. The model will use the results and functions derived from the fill-waste mechanistic and kinetic studies and incorporate them into existing fill-materials-consolidation models as much as possible. While a number of models and theories concerning soil and ballast compaction exist, the problem with the dome-fill material 
(especially in the third scenario) concerns material consolidation in a chemically reactive environment, so that models based only on physical properties and interactions may require certain modifications.

The predictive model is expected to include several subrout thes that use, to as great an extent as possible, model algorithms that have been used to predict similar interactions and foundation settlements. These subroutiries will be composed of existing consolidation, subsidence, and phase equilibrium models to provide a predictive capability of waste/fill/dome and subsequent barrier settlements for all SSTs. The model will be peer reviewed during and after development.

\subsubsection{Economic Considerations}

In the course of any screening method to determine candidate materials for a specific application, cost and ease of avallability are a very important set of factors. They are especially important for this option (dome-fill) of in-tank disposal, since this is meant to be a cost-effective and convenient method. The material should also be available in large quantities and at short notice, since this disposal option may turn out to be a viable one for a lot more SSTs than is being expected now. Most of the candidate matertals being considered so far should be abundantly available.

\subsubsection{Transportation and Handling Considerations}

In addition to the cost and ease of avaijability of a particular material, any constraints to its handling or transportation from the site of availability to the site of use will add to its cost. This is an especially important consideration because the fill material is needed in bulk and within easy access to the SST farm. Conveyors, feed hopper, and accessories will be required to move the designated fill material from the stockpile to the fill tube of the tanks, so that no heavy equipment will be required to be operated within the tank farm.

\subsection{PRIMARY SELECTION METHODS}

Having compiled a 1 ist of screening criteria for fill materials, a discussion of how to use the screening criteria to arrive at a preliminary list 
of candidate fill materials follows. A comparison of the number of criteria that each preliminary candidate material satisfies will be presented in the form of a properties matrix. In addition to the primary individual materials, composite fill-materials or mixtures of the basic materials identified in the list will also be considered as potential candidates. The next important criterion to be considered in the evaluation of the stability of candidate fillmaterials is the extent of its dissolution and reaction rate with the waste, and the maximum extent of both that can be tolerated before the fill-material is eliminated from further consideration.

\subsubsection{Comparative Analysis of Fill-Material Properties}

A comparative analysis of the properties of the candidate fill materials will be one by cross-checking them against the list of screening criteria that has already been established. There is no definitive set of values for the material properties that will be considered, since the composition and state of the wastes in the different SSTs vary widely. One set of limiting criteria may be appropriate for a given tank or an entire tank farm, but may be totally inappropriate for another tank (or tank farm). Therefore, the selection of the candidate fill materials will be made on the basis of a qualitative evaluation of the different material properties amongst each other, for a given set of target waste properties (that are known so far). The initial list at this stage of the discussion includes some common and some not so common materials (see Tables 5.1 and 5.2), including the following classes of materials:

- silicates (basalt, clay, granite, quartzite, slate, gneiss, bentonite, attapulgite)

- carbonates (calcite or limestone, dolomite)

- oxides (rutile, magnetite, hematite, ilmenite)

- sulphate (gypsum)

- phosphate (apatite)

- others (concrete, zeolites, composites or mixtures of materials). 


\section{TABLE 5.1. Physical Properties of Some Common Minerals ${ }^{(a)}$}

\begin{tabular}{|c|c|c|c|c|c|}
\hline \multirow[b]{2}{*}{ Material } & \multirow[b]{2}{*}{ Mol. Wt } & \multirow{2}{*}{$\begin{array}{l}\text { Density or } \\
\text { Sp. Gr./ } \\
\text { Hardness } \\
\end{array}$} & \multicolumn{3}{|c|}{ Solubility $(\mathrm{gm} / 100 \mathrm{cc})$} \\
\hline & & & $\begin{array}{l}\text { Cold } \\
\text { Water } \\
\end{array}$ & $\begin{array}{c}\text { Hot } \\
\text { Water } \\
\end{array}$ & Others \\
\hline $\begin{array}{l}\text { Dolomite } \\
\left(\mathrm{CaCO}_{3} \cdot \mathrm{MgCO}_{3}\right)\end{array}$ & 184.41 & $2.872 / 3.5-4$ & 0.932 & -- & -- \\
\hline $\begin{array}{l}\text { Rutile } \\
\left(\mathrm{TiO}_{2}\right)\end{array}$ & 79.90 & $4.26 / 6-6.5$ & $i$ & 1 & $\begin{array}{l}\mathrm{SH}_{2} \mathrm{SO}_{4} \\
\text { alkali }\end{array}$ \\
\hline $\begin{array}{l}\text { Hemat ite } \\
\left(\mathrm{Fe}_{2} \mathrm{O}_{3}\right)\end{array}$ & 159.69 & $5.24 / 5-6$ & $i$ & $i$ & $\mathrm{sHCl}, \mathrm{H}_{2} \mathrm{SO}_{4}$ \\
\hline $\begin{array}{l}\text { Hemimorphite } \\
\left(2 \mathrm{ZnO} \cdot \mathrm{SiO}_{2} \cdot \mathrm{H}_{2} \mathrm{O}\right)\end{array}$ & 240.84 & $3.45 / 5$ & $i$ & $i$ & -- \\
\hline $\begin{array}{l}\text { Willemite } \\
\left(\mathrm{Zn}_{2} \mathrm{SiO}_{4}\right)\end{array}$ & 222.82 & $4.163 / 5.5$ & $i$ & $i$ & s acids \\
\hline $\begin{array}{l}\text { Wollastonite } \\
\left(\mathrm{CaSiO}_{3}\right)\end{array}$ & 116.16 & $2.5 / 4.5-5$ & -- & -- & $-\sim$ \\
\hline$\left.\underset{\left(\mathrm{CaSO}_{4}\right.}{\text { Gypsum }} \cdot 2 \mathrm{H}_{2} \mathrm{O}\right)$ & 172.17 & $2.32 / 2$ & 0.241 & 0.222 & $s$ acids \\
\hline $\begin{array}{l}\text { Perovskite } \\
\left(\mathrm{CaTiO}_{3}\right)\end{array}$ & 135.98 & $4.10 / 5.5$ & -- & -- & -- \\
\hline $\begin{array}{l}\text { Calcite } \\
\left(\mathrm{CaCO}_{3}\right)\end{array}$ & 100.69 & $2.71 / 3$ & 0.0014 & 0.0018 & s acids \\
\hline $\begin{array}{l}\text { Wurtzite } \\
(\operatorname{ZnS})\end{array}$ & 97.43 & $3.98 / 3.5-4$ & 0.00069 & -- & s acids \\
\hline $\begin{array}{l}\text { Magnet ite } \\
\left(\mathrm{Fe}_{3} \mathrm{O}_{4}\right)\end{array}$ & & $5.175 / 5.5-6.5$ & & & \\
\hline $\begin{array}{l}\text { Apatite } \\
\left(\mathrm{Ca}_{5}\left(\mathrm{PO}_{4}\right)_{3}(\mathrm{OH}, \mathrm{F}, \mathrm{Cl})\right)\end{array}$ & & $3.1-3.35 / 5$ & & & . \\
\hline $\begin{array}{l}\text { Gibbsite } \\
\left(\mathrm{A} /(\mathrm{OH})_{3}\right)\end{array}$ & & $2.4 / 2.5-3.5$ & & & \\
\hline
\end{tabular}

\footnotetext{
Some radionuclide or liquid waste sorbents like zeolites, clays, and aluminas (bauxite or gibbsite) are also considered. A few representative zeolites are listed below. Some of them, including clinoptolite, have been considered before because of their abilities to selectively absorb certain radionuclides, like cesium-137 from waste slurries and mixtures.
}

Zeolites:

$\begin{array}{ll}\text { Natrolite } & 2.20-2.26 / 5 \\ \left(\mathrm{Na}_{2} \mathrm{Al}_{2} \mathrm{Si}_{3} \mathrm{O}_{10} \cdot 2 \mathrm{H}_{2} \mathrm{O}\right) & \\ \text { Mesolite } & \sim 2.26 / 5 \\ \left(\mathrm{Na}_{2} \mathrm{Ca}_{2}\left(\mathrm{Al}_{2} \mathrm{Si}_{3} \mathrm{O}{ }_{10}\right) \cdot 8 \mathrm{H}_{2} \mathrm{O}\right) & \\ \text { Scolec ite } & 2.25-2.29 / 5 \\ \left(\mathrm{CaAl}_{2} \mathrm{Si}_{3} \mathrm{O}\right. & \end{array}$


TABLE 5.1. (contd)

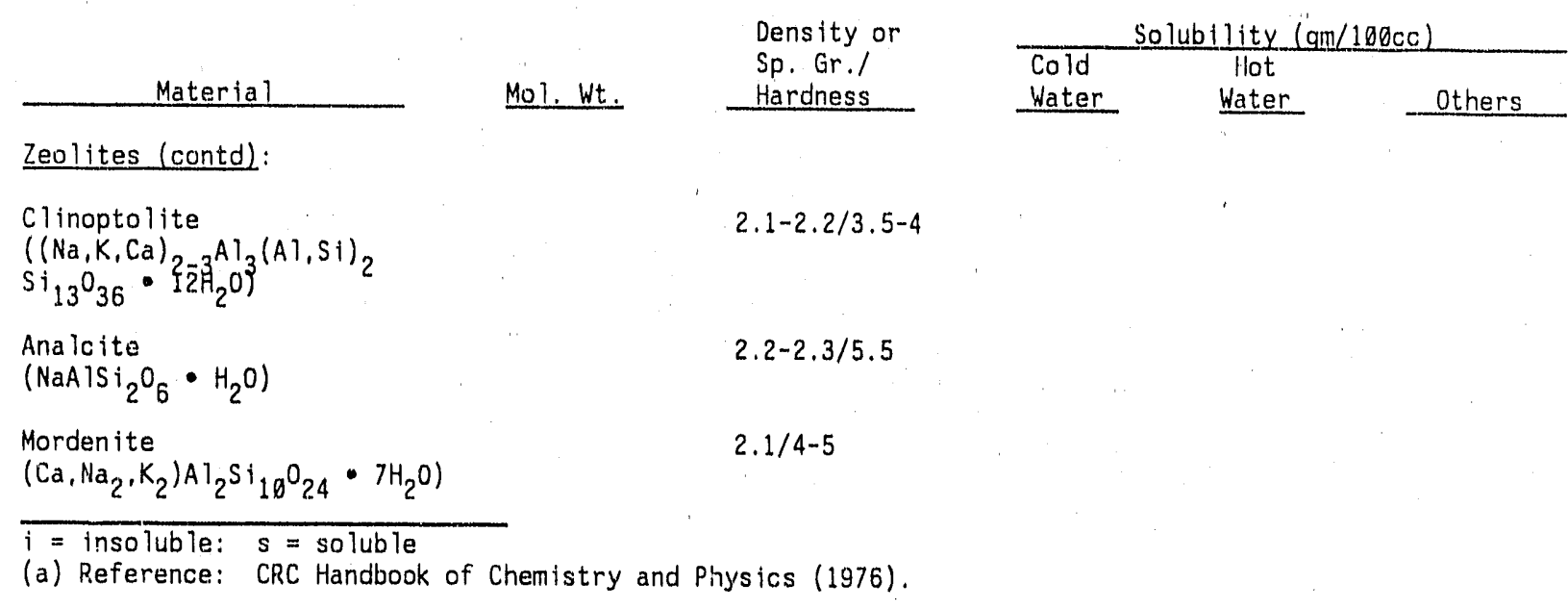

TABLE 5.2. Additional Physical Properties of Common Minerals(a) Thermal $\underset{k}{\text { Conductivity }} \quad \begin{gathered}\text { Specific Heat Comp. Strength } \\ C_{p}\end{gathered}$

\begin{tabular}{|c|c|c|c|c|}
\hline Material & $(\mathrm{Btu} / \mathrm{h} \mathrm{ft} \mathrm{F)}$ & $(W / m K)$ & $(c a) / g c)$ & $\left(\mathrm{N} / \mathrm{m}^{2}\right)$ \\
\hline Granite & 1.60 & 2.77 & 0.2 & $1.05-2.72$ \\
\hline Basa7t & \multicolumn{3}{|c|}{ properties similar to granite } & $2.21-7.78$ \\
\hline Sandstone & 1.057 & 1.83 & 0.26 & $1.07-9.79$ \\
\hline Gneiss & \multicolumn{3}{|c|}{ properties similar to granite } & $1.06-9.6$ \\
\hline Gypsum & 0.28 & 0.48 & & 1.25 \\
\hline Limestone & 0.75 & 1.30 & 0.20 & $1.5-9.94$ \\
\hline Marble & 1.44 & 2.50 & 0.20 & $1.5-9.94$ \\
\hline Dolomite & 0.389 & 0.674 & - & $1.13-8.96$ \\
\hline Hematite & \multicolumn{3}{|c|}{ properties similar to rutile } & $1.19-6.07$ \\
\hline Shale & 0.420 & 0.73 & 0.17 & $1.12-9.27$ \\
\hline Rutile $\left(\mathrm{TiO}_{2}\right)$ & 0.15 & 0.26 & & \\
\hline Asbestos & 0.087 & 0.15 & & \\
\hline
\end{tabular}

(a) Reference: CRC Handbook of Physical Properties of Rocks (Vol. II) (1982). 
Based on the physical properties listed above, a qualitative comparison can be made of the different candidate fill materials:

- Density: Zeolites, carbonates, sulphate (gypsum), and phosphate (apatite) are better than oxides (magnetite and hematite).

- Hardness: Zeolites, silicates (willemite), oxides (magnetite, hematite, rutile) are preferable.

- Solubility: Sulphate (gypsum), carbonates (calcite) are not good candidates, unless used with other insoluble materials as a combination fill-material. Oxides (magnetite, hematite, rutile), silicates (willemite) are good candidates, by themselves.

- Thermal Conductivity: Asbestos, gypsum, rutile, dolomite are good insulators. Granite, marble, sandstone are good conductors.

- Specific Heat: All materials have comparable values $(\sim 0.2 \mathrm{cal} / \mathrm{g} \mathrm{C})$.

- Compressive Strength: Limestone, basalt, gneiss, sandstone, dolomite are good. Shale, hematite are moderate. Granite, gypsum are poor.

\subsubsection{Analysis of Composite Fill Materials}

In addition to materials of a single chemical composition, certain mixtures or composites of the basic materials will also be considered for screening purposes at this first level of evaluation. Consideration will also be given to using a combination of two or more materials, where one material is essentially used as a layering material and comes in direct contact with the waste, while a second material may be used for filling the rest of the void in the tank. As an example of a possible pairing of fill materials, an initial layer of zeolites or bentonite (or a mixture of the two) could be placed at the bottom of the tank to sorb liquid waste and immobilize the hazardous elements. The waste material may also be cemented or grouted, first. The remaining void space could then be filled with gravel or crushed basalt as had been considered earlier. Additional materials will be added to the primary list as they become known while the study is in progress. 


\subsubsection{Reaction Rates/Tolerable Dissolution}

It is anticipated that most (if not 211) of the candidate fill materials will have some chemical interaction with the radioactive waste, either immediately before or after an extended exposure. The extent of the reactivity and its determination turns out to be one of the more important criteria in the selection of the fill materials. The amount of moisture in the tanks will be an important factor in determining the extent of reaction between the waste and the fill materials. Also, the alkalinity of the waste is an important consideration, since part of the process of tank consolidation may be to add certain materials (pretreatment process) to the tank to reduce the alkalinity and, therefore, its $\mathrm{pH}$ value. This would alter the strategy of the selection of fill materials considerably, since the waste in the tank will not be as caustic or have as much hydroxide as in the untreated tank.

\subsection{PROPOSED TESTING APPROACHES}

The candidate fill materials (after this first screening) will be tested both in the laboratory and in the field tu determine their physical and chemical stability under the conditions expected in the waste tanks. In this second stage of the screening process, the fill material will be initially exposed to synthetic neutralized bismuth-phosphate process waste, synthetic neutralized PUREX process waste, and synthetic neutralized REDOX process waste. These are representative of the three main waste types that may be stored in the Hanford SSTs (KTem 1990). Some of the other Hanford Site wastes will also be identified whose composition may have a detrimental effect on the candidate dome-fill materials. Both short-term tests (at higher temperatures, up to $250^{\circ} \mathrm{C}$ ) and long-term tests (at lower temperatures, up to $100^{\circ} \mathrm{C}$ ), for as long as 280 days, wi11 be conducted. Similar tests will be conducted with actual wastes recovered from a number of selected tanks in the farm. Tests with actual wastes are important because the tank wastes may contain other constituents, such as organic complexants or other complexing agents, that may significantly affect reaction rates in the waste/fill material systems. Also, 
a comparison of the results of studies with synthetic and actual wastes for a given fill-material will provide proof of the validity of using synthetic wastes for future tests.

Further longer-term tests carried out for a minimum of 3 to 5 years with both synthetic and actual tank wastes would be required to confirm the results at higher temperatures and to determine the longer-term effects at lower temperatures. The effects of varying the amount of water present in the fil1 material/waste mix should also be determined over the range of expected temperatures because of uncertainties in the water contents of the tanks over the required containment times. An associated uncertainty is the role played by the larger amount of free water present in the $100^{\circ} \mathrm{C}$ tests.

Essentially, two types of tests will be conducted on the dome-fill candidate materials: chemical reactivity/durability tests, and material compaction tests with waste systems. The chemical tests are similar to and adapted from established chemical durability tests that have been developed for nuclear waste-form testing. These chemical tests are generally designed to obtain kinetic data (Mendel 1981). Tests will be conducted both above and below $100^{\circ} \mathrm{C}$, using appropriate containers or autoclaves. The bulk of the testing conducted above $100^{\circ} \mathrm{C}$ will be done with digestion bombs that will require quenching before fluid sampling, but a few tests will be done in rocking autoclave systems with capabilities for liquid sampling at temperature. Both monolithic and powder samples will be used. Both the liquids and solids (after the reaction) will be appropriately characterized, including reaction product identification, to determine time-dependent changes and reaction limits. For some kinetic model applications, including thermal effects, it is necessary to evaluate the initial (or forward) leach rate of the materials to determine the dissolution rate before any solid reaction or precipitation occurs. These types of tests will also be included.

Compaction tests will be conducted with commercial instruments that have been developed for soil consolidation tests. Some modification may be neces. sary for large particle size applications, but is not expected at this time. Test procedures will be based on generally accepted procedures, such as ASTM-D 2435-80 (Standard Test Method for "One Dimensional Consolidation Properties of 
Sol1s"). Other more efficient testing methods may be used in place of the traditional test, if appropriate (01son 1986). In addition, spectal column studies may also be developed to evaluate the time-dependent consolidation of the dome-fill material in a rectrculating waste system to accelerate possible waste-fill reactions and measure compaction during the reactions.

\subsection{PRELIMINARY LIST OF DOME-FILL MATERIALS}

Below, a preliminary list of candidate dome-fill materials is provided at the end of the first screening process to further evaluate the applicability of the screening criteria and for physical and chemical testing with wastes.

- Silicates such as basalt, gneiss, bentonite, and phosphates such as apatite are good candidates.

- Carbonates such as calcite and dolomite may be used in combination with absorbent materials such as zeolites, gibbsite and clays.

- Oxides such as magnetite, hematite, and rutile have to be tested further for the consolidation of the waste-fill mixture, since they are comparatively heavier than the known waste density.

- Other composites or mixtures of materials such as grout mixtures (cement-slag-clay) and others with concrete, clay, and zeolites, will be considered as will synthetic materials such as ceramics.

This is only a preliminary list, and it is anticipated that more fillmaterial candidates will be added as the testing phase progresses in the next couple of years. The list will also be expanded as more information becomes available regarding the presence of wastes or otherwise, among the candidate tank farms for the dome-fill scenario option of onsite disposal of singleshe11 tanks. 


\subsection{REFERENCES}

Adams, M. R., R. A. Carlson, R. S. McBeath, and R. C. Routson. 1987. Dome-fill Technology Development Plan. WHC-EP-0014, Westinghouse Hanford Cumpany, Richland, Washington.

Carlson, R. A., and R. S. McBeath. 1986. Dome-fill Technology Development Plan. RHO-RE-PL-36, Rockwel1 Hanford Operations, Richland, Washington.

Carmichae1, R. S., ed. 1982. Handbook of Physical Properttes of Rocks. CRC Press Inc., Boca Raton, Florida.

F1yckt, D. L. 1985. TY Demonstration-Destgn Criteria. SD-WM-CR-020, Rockwe11 Hanford Operations, Richland, Washington.

Klem, M. J. 1990. Inventory of Chemicals Used at Hanford Site Production Plants and Support Operations (1944-1980). WHC-EP-0172, Rev. 1.0, Westinghouse Hanford Company, Richland, Washington.

Klem, M. J., C. E. Golberg, R. D. Gibby, K. A. Giese, F. A. Ruck, J. C. Sonnichsen, D. D. Wanner, N. R. Wing, K. A. Woodworth, and

J. F. Fletcher. June 1990. Single-Shell Tank Systems Technical Support Program Plan. WHC-EP-0288, Westinghouse Hanford Company, Richland, Washington.

Keller, J. F., M. G. Woodruff, A. J. Schmidt, P. L. Hendrickson, and K. B. Selby. 1989. Requlatory Requirements Important to Hanford Sinqle-Shell Tank Waste Management Decisions. PNL-6821, Pactfic Northwest Laboratory, Richland, Washington.

Mende1, J. E., compiler. 1981. Nuclear Waste Materials Handbook-Waste Forms Test Methods. DOE/TIC-11400, prepared by Pacific Northwest Laboratory for the U.S. Department of Energy, Washington, D.C.

Metz, W. P., and W. E. Ogren. 1976. Criteria: Waste lank Isolation and Stabilization. ARH-CD-784, Atlantic Richfield Hanford Company, Richland, Washington.

01 son, R. E. 1986. "State of the Art: Consolidation and Testing." In Consolidation of Solls: Testing and Evaluation, eds. R. N. Yong and F. C. Townsend, pp. 203-216, ASTM STP 892, American Soctety for Testing and Materials, Philadelphia.

Powers, H. G. 1988. Hanford Waste Management Technology Plan Calendar Year 1988. WHC-EP-0212, Westinghouse Hanford Company, Richland, Washington.

Risenmay, H. R. 1986. Physical Interactions Between Hanford Single-Shell Tank Wastes and Fill Material. Proceedings of the Waste Management ' 86 Conference, March 2-6, 1986, pp. 537-540. 
Routson, R. C. 1983. Possible Weathering (Dissolution) of Basalt Dome-Filling Materlal in 241-TY Tank Farm Waste. RHO-HS-EV-20 P, Rockwe11 Hanford Operations, Richland, Washington.

U.S. Department of Energy (DOE). 1989. Draft Single-She11 Tanks System Closure/Corrective Action Work Plan. DOE-RL 89-16, Draft A, Richland, Washington.

Washington State Department of Energ.y, U.S. Environmental Protection Agency, and U.S. Department of Energy (WDOE, EPA, and DOE). 1989. Hanford Federal Eacility Agreement and Consent Order.

Weast, Robert C., ed. 1976. Handbook of Chemistry and Physics. 56th Edition. CRC Press Inc., Cleveland, Ohio.

Weiss, R. L. 1986. TY Tank Farm Waste Charactertzation Data. RHO-WM-TI-1 P, Rockwell Hanford Operations, Richland, Washington.

Wiater, P. J., and B. A. Higley. 1977. Subsurface Stabilization by Grouting of a Simulated Underground Tank. ARH-CD-877, At7antic Richfleld Hanford Company, Richland, Washington.

Wing, N. R., and G. W. Gee, eds, 1990. Hanford Site Protective Barrier Development Program: Fiscal Year 1989 Highliahts. WHC-EP-0318, Westinghouse Hanford Company, Richland, Washington.

Winters, W. I., L. Jensen, L. M. Sasaki, R. L. Weiss, J. F. Keller, A. J. Scmidt, and M. G. Woodruff. May 1989. Waste Characterization Plan for the Hanford Single-She11 Tanks. WHC-EP-0210, Westinghouse Hanford Company, Richland, Washington. 


\section{DISTRIBUTION}

No. of

Coptes

\section{OFFSITE}

12 DOE/Office of Scientific and Technical Information

\section{T. Evans}

U.S. Department of Energy (HQ) $E M-55$

12800 Middlebrook Rd., SU400 Germantown, MD 20874

K. Stevenson

U.S. Department of Energy

376 Hudson Street

New York, NY 10014-3621

D. Berry

Department 6620

Sandia National Laboratories

Albuquerque, NM 87545

J. Blakeslee

EG\&G Rocky Flats, Inc.

Technology Development

P.0. Box 464

Golden, CO 80402-0464

R. A. Carrington

Plans \& Programs Division

MSE, Inc.

P.0. Box 3767

Butte, MT 59702

P. Colombo

Brookhaven National Lab

Building 703-50 Rutherford

Upton, NY 11973

J. Corones

108 Office \& Laboratory

Building

Iowa State University

Ames, IA 50011
No. of

Eoptes

\section{Emtlia}

Strategic Planning Department

Chem-Nuclear Geotech

P.0. Box 14000

Grand Junction, co 81502-2567

R. B. Evans

Environmental \& Health Division

Reynolds Electrical \& Eng. Co. P.O. Box 98521

Las Vegas, NV 89193-8521

B. Gupta

Solar Thermal Electric Program

Solar Energy Research Institute

1617 Cole Boulevard

Golden, CO 80401

W. J. Haas, Jr.

Ames Laboratory

Room 7 Spedding

Iowa State University

Ames, IA 50011

J. E. Helt

Director, Office of Waste

Management Programs

9700 South Cass Avenue

Argonne, IL 60439-4837

A. C. Heywood

Science Applications International Corp.

Pleasanton, CA 94588

J. P. Hopper

Technical Project Manager

Westinghouse Materials Co. of Ohio

P.0. Box 398704, MS: 51

Cincinnati, $\mathrm{OH} 45239$ 
No. of

Coptes

$R$, Jacobson

University of Nevada

Water Resources Center

Sulte 1,

2525 Chandler Avenue

Las Vegas, NV 89120

P. D. Kalb

Brookhaven National Lab

Building 703-50 Rutherford

Upton, NY 11973

A. Malinauskas

Waste Research \& Development.

Programs

P.0. Box 2008

Oak Ridge, TN 37831-6135

T. McEvilly

Lawrence Berkeley Laboratory, $50 \mathrm{E}-11$

1 Cyclotron Road

Berkeley, CA 94720

F. Poucher

Energy Programs and Adv.

Planning

P.0. Box 1449-D/6222, T038

Canoga Park, CA 91304

J. P. Shipley, Jr.

ET-EET

Los Alamos National Lab, MS F643

Los Alamos, NM 87545

J. D. Smyth

CH2M Hill Inc.

1933 Jadwin

Richland, WA 99352
No. of

Copies

J. L. Steele

Waste Environmental

Remedlation Programs

Savannah River Site

SRL, 773 A, A208

Aiken, SC 29802

S. L. Stein, Environmental Management Org.

Battelle Seattle Research Center

4000 N.E. 41st Street

Seattle, WA 98105

R. R. Stiger

Waste Technology Development

EG\&G Idaho, Inc.

P.O. Box 1625

Idaho Falls, ID 83415-3940

T. R. Thomas

Westinghouse Idaho Nuclear Company, Inc.

P.0. Box 4000

Idaho Falls, ID 83403-4000

J. Tipton

Assistant Operations Manager

Remove Sensing Laboratory

P.0. Box 1912, MS D-12

L.as Vegas, NV 89125

C. L. Valle

Allied Signal Aerospace

Kansas City Plant

P.0. Box 419159, D/272, FV43

Kansas City, MO 64141-6159 
No. of

Coptes

J. L. Yow

Lawrence Livermore Laboratories

P.0. Box 808, MS: L-207

Livermore, CA 94550

\section{ONSITE}

6 DOE Richland Field Office

P. K. Clark

J. M. Hennig (5)

A5-21

$A 5-21$

17 Westinghouse Hanford Company

J. D. Berger

A. L. Boldt

LO- 18

K. D. Boomer

H5- 49

J. W. Cammann

H5- 49

T. E. Gates

H4- 14

L5 -63

J. S. Garfield

E. W. Gerber

R. L. Gilchrist

W. O. Greenhalgh

B. A. Higley

J. J. Holmes

J. A. Hunter

M. J. Klem

A. A. Kruger

M. J. Kupfer

G. E. Stegen

B. A. Wolfe
R3 -63

L5-62

L5 -63

L.5-3!

H5- 49

L5 - 55

L5-31

R2 -14

R4 - 03

H5 -49

G6 -06

L.5-55
No, of

Coptes

49 Pacific Northwest Laboratory

E. G. Baker

J. W. Buck

$k_{2}-12$

L. R. Bunnel.1

P. J. Chamberlain

$K 6-96$

P8-44

R. E. Einziger

K7-34

J. F. Fletcher

P7-14

$\mathrm{K} 6-31$

M. A. Gerber

$\mathrm{K} 2-12$

R. T. Hallen

L. K. Holton, Jr.

P. R. Hrma

B. M. Johnson

$E$. 0 . Jones

R. 0. Lokken

J. L. McElroy

G. W. McNair

D. R. Payson

P. Sliva

P. A. Scott

J. W. Shade (10)

S. C. Slate

S. Somasundaram (10)

J. L. Straalsund

D. M. Strachan

R. S. Wegeng

J. H. Westsik, Jr.

Publishing Coordination

Technical Report Files (5)

$\mathrm{K} 2-12$

P7 -43

P8-37

K.1-51

$\mathrm{K} 2-12$

P8-37

P7 -46

K6-25

$K 6-35$

P8-44

P7 -43

P8-37

$k 1-25$

$\mathrm{K} 5-19$

K1-79

K2- 44

K $6-28$

P7-43

Kaiser Enqineers Hanford Company

D. L. Rittenhouse

E6-26

Distr. 3 

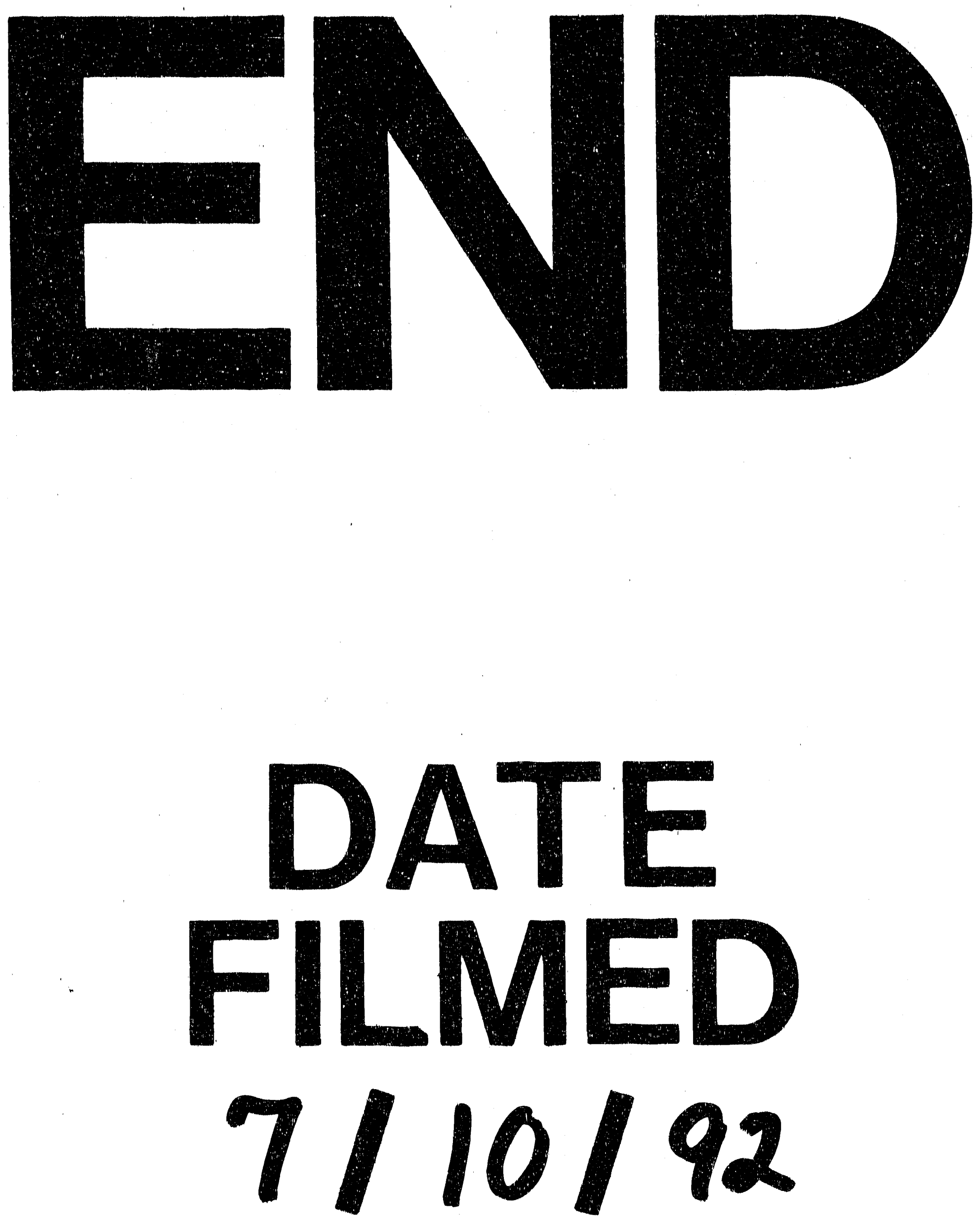
